\title{
Evaluating the market splitting determinants: evidence from the Iberian spot electricity prices
}

\author{
Nuno Carvalho Figueiredo ${ }^{\mathrm{a}, \mathrm{c}, *}$, Patrícia Pereira da Silva ${ }^{\mathrm{b}, \mathrm{c}}$, Pedro A. Cerqueira ${ }^{\mathrm{b}, \mathrm{d}}$ \\ ${ }^{a}$ Energy for Sustainability Initiative - University of Coimbra, Sustainable Energy Systems - MIT-P, Portugal \\ ${ }^{\mathrm{b}}$ Faculty of Economics - University of Coimbra, Av. Dias da Silva, 165, 3004-512 Coimbra, Portugal \\ ' INESC Coimbra, Rua Antero de Ouental, 199, 3030-030 Coimbra, Portugal \\ d GEMF, Grupo de Estudos Monetários e Financeiros, Coimbra, Portugal
}

\section{H I G H L I G H T S}

- Assess determinants on market splitting behaviour of Iberian electricity markets.

- Logit and non-parametric models to express market splitting probability response.

- Explanatory variables: wind, hydro, thermal and nuclear power; ATC and demand.

- Results: increase of market splitting probability with higher availability of low marginal cost electricity.

- Coordination policies governing both interconnections and renewables deployment.

\section{A R T I C L E I N F O}

\section{Article history:}

Received 20 January 2015

Received in revised form

3 June 2015

Accepted 4 June 2015

Available online 17 June 2015

Keywords:

Market Splitting

Renewable Energy

Non-parametric models

\begin{abstract}
A B S T R A C T
This paper aims to assess the main determinants on the market splitting behaviour of the Iberian electricity spot markets. Iberia stands as an ideal case-study, where the high level deployment of wind power is observed, together with the implementation of the market splitting arrangement between the Portuguese and the Spanish spot electricity markets.

Logit and non-parametric models are used to express the probability response for market splitting of day-ahead spot electricity prices as a function of the explanatory variables representing the main technologies in the generation mix: wind, hydro, thermal and nuclear power, together with the available transfer capacity and electricity demand. Logit models give preliminary indications about market splitting behaviour, and then, notwithstanding the demanding computational challenge, a non-parametric model is applied in order to overcome the limitations of the former models.

Results show an increase of market splitting probability with higher wind power generation or, more generally, with higher availability of low marginal cost electricity such as nuclear power generation.

The European interconnection capacity target of $10 \%$ of the peak demand of the smallest interconnected market might be insufficient to maintain electricity market integration. Therefore, pro-active coordination policies, governing both interconnections and renewables deployment, should be further developed.
\end{abstract}

(c) 2015 Elsevier Ltd. All rights reserved.

\section{Introduction}

The single market for electricity is a substantial part of the European internal energy market. After the required unbundling of the electricity sectors, wholesale electricity markets were implemented and then partially joined through regional electricity markets (ERGEG, 2006; Karova, 2011; Meeus and Belmans, 2008).

\footnotetext{
* Corresponding author at: Energy for Sustainability Initiative - University of Coimbra, Sustainable Energy Systems - MIT-P, Portugal

E-mail address: nuno.figueiredo@portugen.com (N.C. Figueiredo).
}

The interaction between electricity markets occurs through high voltage (HV) cross-border interconnections with limited capacity, offering numerous advantages under normal operating conditions; such as optimal power station daily production, increasing opportunities for operation with renewable energies, the promotion of competition and enhancement of supply security. Several authors have studied electricity market integration, addressing different geographic areas: De Vany and Walls (1999), Park et al. (2006) in the US regional markets; Worthington et al. (2005) and Higgs (2009) in Australia; Armstrong and Galli (2005), Zachmann (2008), Bosco et al. (2010), Bunn and Gianfreda (2010), Pellini 
(2012a) and Figueiredo and Silva (2012 and 2013) in Europe. Regarding the South-west regional electricity market, composed of France, Portugal and Spain, all studies are unanimous in establishing that there is integration between both Iberian electricity markets (Mibel) in the period analysed in this study. France has not been found to be integrated with the Iberian markets, as analysed by these authors.

The electricity generation mix is changing in Europe with the increasing penetration of Renewable Energy Sources Electricity (RES-E). The impact of high penetration of RES-E has been discussed throughout a number of scientific papers and reports. In particular, some of the issues discussed related with the high level growth of wind power installed capacity reported are: the importance of adequate interconnections and transmission capacities to transport excess production, electrical system fault endurance, available and flexible standby generating capacity to accommodate load variability and effective control or curtailment of wind power production (Benatia et al., 2013; Franco and Salza, 2011; Söder et al., 2007). Also wind forecasting is fundamental to allow wind power load management and electrical system balancing (Milligan et al., 2009). Due to the almost inexistent marginal costs of RES-E generation, they are the first in the merit order of power plant dispatch. Therefore, by displacing higher marginal cost electricity generation, one could expect some level of decrease in the electricity spot market prices. This fact is reported by several authors (Amorim et al., 2010; Cruz et al., 2011; Cutler et al., 2011; Gelabert et al., 2011; Jónsson et al., 2010; Klessmann et al., 2008; Mauritzen, 2010; Moreno et al., 2012; Mulder and Scholtens, 2013; Sáenz de Miera et al., 2008; Sensfuß et al., 2008) and implies the hypotheses of increasing the cross-border transit of electricity, therefore market splitting.

The integration of the European electricity markets together with the fast expansion of renewable generation is thus creating one of the most demanding challenges to transmission grids and their operation (Henriot et al., 2013; Ragwitz et al., 2012). The large deployment of RES-E, with related increasing electricity flows at particular climate conditions can create congestions, leading to strengthening requirements of transmission grids throughout European Member states. Moreover, cross-border interconnections are increasingly essential for the targeted European electricity market integration, which, with the observed high availability of renewable generation, might not be sufficient for the required commercial electricity transits. Literature is scarce on the assessment of the impacts that high penetration of RES-E generation have on interconnected market behaviour and specifically on market coupling. The only study found addressing this issue was done for the Electricity Reliability Council of Texas (Woo et al., 2011), considering the influence of the existing high wind power penetration on the behaviour of the market coupling arrangement.

This study addresses the market splitting behaviour of the Iberian electricity spot market, through parametric and nonparametric probability response models, using data from the $1 \mathrm{st}$ July 2008 until the 31st December 2012. This approach brings a new perspective on the use of non-parametric models in the assessment of electricity markets. Therefore, the research questions are twofold: (a) does increasing renewable power generation increase market splitting probability of occurrence?; and (b) does empirical data confirm the available cross-border interconnection capacity influence on market splitting?

In this Section overviews of the EU legislative framework and the Iberian electricity markets are presented. Additionally, a summary of the renewables deployment and cross-border interconnections in Iberia is made. Data and model specification used in this study are presented in Section 2, followed by the obtained results in Section 3. In Section 4 the analysis and discussion of the results is provided. Section 5 concludes with some policy recommendations.

\subsection{A brief overview of the EU legislative framework}

The objectives set for the European energy policies were to: guarantee the supply of electricity, reduce costs, foster competition, ensure security of supply, and protect the environment. The European Directive 96/92/EC established for the first time common rules for the various electricity markets in Europe, based on the liberalisation of the sector without prejudice of the public service required and the access by the generators and consumers to the transmission and distribution grids (Jamasb and Pollitt, 2005).

These requirements are guaranteed by regulating authorities established in each country (Silva and Soares, 2008). The adequate integration of national electricity transmission grids and associated increase of electricity cross-border transfers aim to ensure the optimisation of the production infrastructure (Jacottet, 2012). However, different levels of market opening and diverse development stages of interconnectors between electricity transmission grids across European countries are observed. In consequence, Member-States took necessary measures to facilitate transit of electricity between transmission grids in accordance with the conditions laid down in the Directives.

In 2006 the European Regulators Group for Electricity and Gas (ERGEG - currently the Agency for the Cooperation of Energy Regulators - ACER) launched seven Electricity Regional Initiatives for the creation of seven regional electricity markets (Karova, 2011; Meeus and Belmans, 2008). The objective for the creation of these regional electricity markets was to provide an intermediate step for the consolidated European Electricity Market (ERGEG, 2006).

Almost simultaneously, the European Directive 2001/77/EC, called for the promotion of electricity generation by renewable energy sources (RES) in Europe. The aim was to reduce dependency on imported fossil fuels and to allow a reduction in Green House Gas (GHG) emissions. The large deployment of RES-E generation in Europe was achieved through a programme of strong financial support mechanisms (Amorim et al., 2013; Jager et al., 2011; Meyer, 2003), like feed-in tariffs, feed-in premia, fiscal incentives, tax exemptions and others. The RES electricity (RES-E) generation in Europe was 467,7 TWh in 2013 consisting of 42.4\% hydroelectric, $27.4 \%$ wind, $10.4 \%$ solar, $9,9 \%$ biomass and $10 \%$ of other renewable technologies (Eurostat, 2015). The RES-E generation technologies are in different stages of development which explain the different shares of deployment achieved in each technology (Brown et al., 2011).

\subsection{The Iberian electricity market}

The agreement reached between the authorities and the electricity companies late in December 1996 (Ministerio de Industria y Energía - Spain, 1996), allowed for electricity sector reform in Spain. The law for the electricity sector was then issued in November 1997, establishing its regulation with the objectives to guarantee the supply, the quality of supply at the minimum possible cost and respect of the environment. Therefore, the existing public service was replaced by the guarantee of supply for all consumers; the electrical sector was privatised on the generation and commercialisation sides and regulated on the transmission and distribution sides (Boletín Oficial del Estado - Spain, 1997). The transmission system was assigned to Red Eléctrica de España (REE) as a regulated monopoly, and in January 1998 an electricity spot market was introduced in Spain (OMEL).

In Portugal, Decree-law 7/91 of the 8th January established the conversion of the existing public electricity company Electricidade de Portugal (EDP) into a private company, however still owned by the state. This allowed the unbundling of the Portuguese 
electricity sector and later its re-privatisation. The re-privatisation of EDP in 1997, after the issue of Decree-law 56/97 of the 14th March, determined on the first phase the sale of $29.99 \%$ of its capital and was followed by several other phases, the last one being in 2012. The transmission system operation was assigned to Redes Energéticas Nacionais (REN), created in 1994, as a regulated monopoly, under the ownership of EDP. By the end of the year 2000 , the Portuguese state had acquired $70 \%$ of REN from EDP and only in 2007 did the initial phase of REN's privatisation take place (Redes Energéticas Nacionais, 2012a). Currently EDP still owns a 5\% share in REN (Redes Energéticas Nacionais, 2012b). The Portuguese regulator for the energy sector (ERSE) was created in 1995 by Decree law $187 / 95$ of 27th July (Diário da República Portuguesa, 1995) and has since then been amended through several other laws related to the energy sector and EU requirements (Silva, 2007).

The Iberian electricity market only became a reality in July 2007 after several years of preparation and negotiation between the Portuguese and the Spanish states. MIBEL is composed by a spot (OMIE) and a bilateral (OMIP) electricity markets (Conselho de Reguladores do MIBEL, 2009). It started operation in July 2007 and by 2008 the corresponding spot electricity market was already trading $88 \%$ of the total demand (Zachmann, 2008). In 2014, trading in Mibel achieved 81\% of the total demand (OMIE, 2013).

Additional details on the Spanish electricity market can be found in Crampes and Fabra (2005), Furió and Lucia (2009) and Garrué-Irurzun and López-García (2009) and on the Portuguese electricity market in Amorim et al. (2010).

In Iberia, wind power installed generation capacity increased substantially as can be observed in Table 1. Furthermore, and with respect to renewables, solar generation in Portugal did not have a similar growth to the one observed in Spain, where it achieved $7 \mathrm{GW}$ of installed capacity. Portugal did not pursue the deployment of solar power generation and, in addition to the already large hydro power share, it concentrated mainly on wind power for the further development of renewable energy sources. Nuclear power has only been developed in Spain. Thermal power increased in Spain after 2002 and until 2010, mainly due to the installation of new combined cycle power plants. The installation of new combined cycle power plants was also done in Portugal, but at a later stage and to a lesser extent. Both in Spain and Portugal a slight decrease can be observed after 2011.

\subsection{Overview of renewables and cross-border Interconnections}

The leading hypothesis considered in this study is that increasing renewable power generation and available cross-border interconnection capacity are the main drivers for market splitting. The following sub-sections provide a brief overview of these two drivers.

\subsubsection{Renewables deployment in Iberia}

The large deployment of RES-E generation and namely of wind power in Europe was achieved by strong financial support mechanisms, including feed-in tariffs, fiscal incentives and tax exemptions (Amorim et al., 2013; Jager et al., 2011; Meyer, 2003). This poses new challenges, both in the technical sense and in the market design. Electricity systems needs restructuring to accommodate RES-E intermittency, namely by increasing the availability of standby and balancing services (Lynch et al., 2012; Mauritzen, 2010). Policy design has to reflect the required market integration of these technologies, knowing that price volatility is prone to increase (Batlle et al., 2012; Benatia et al., 2013).

In Iberia, both the Portuguese and the Spanish wind power sectors were successfully developed (Batlle, 2011; Gelabert et al., 2011; Moreno and Martínez-Val, 2011; Ruiz Romero et al., 2012), following the European Union (EU) targets for the promotion of RES-E, aiming to reduce dependency on imported fossil fuels and allowing for the reduction in greenhouse gas emissions (European Union, 2009a, 2001). Comparing the hourly demand profile with the wind power installed capacity evolution in Iberia, to the adequate climate conditions, wind power can supply a large share of electricity to the system. It is also noticable that the share of wind power installed capacity over total installed generation capacity is approximately the same. Therefore, Iberia stands as an ideal case-study, where the high level deployment of wind power is observed, together with the early implementation of the market splitting arrangement between both spot electricity markets.

\subsubsection{Cross-border interconnections}

The Transmission System Operators (TSOs) are mostly ruled through the implementation of national regulations. These have been progressively adapted towards a single set of rules pushed by the European Union, aiming for an efficient integrated market. The key responsibility to manage cross-border interconnections constraints is specifically ruled by European Union Regulation 1228/ 2003/EC of 26 June 2003, which was later repealed by European Union Regulation 714/2009 of 13 July 2009 (European Union, 2009b, 2003), aiming to enhance competition, establish a compensation mechanism for cross-border flows of electricity, setting principles on cross-border transmission charges and allocating available capacities. Since then, the European Network of Transmission System Operators (ENTSO), created under the so called

Table 1

Iberian installed generation capacities [MW] (Eurostat, 2015).

\begin{tabular}{|c|c|c|c|c|c|c|c|c|c|c|c|c|c|}
\hline \multicolumn{7}{|c|}{ Portugal } & \multicolumn{7}{|l|}{ Spain } \\
\hline Year & Thermal & Nuclear & Hydro & Wind & Solar & Total & Year & Thermal & Nuclear & Hydro & Wind & Solar & Total \\
\hline 2000 & 6275 & 0 & 4535 & 83 & 1 & 10894 & 2000 & 26243 & 7503 & 17960 & 2206 & 12 & 53924 \\
\hline 2001 & 6291 & 0 & 4560 & 125 & 1 & 10977 & 2001 & 26915 & 7519 & 18032 & 3397 & 16 & 55879 \\
\hline 2002 & 6448 & 0 & 4583 & 190 & 1 & 11222 & 2002 & 29941 & 7577 & 18068 & 4891 & 20 & 60497 \\
\hline 2003 & 6749 & 0 & 4583 & 268 & 2 & 11602 & 2003 & 37310 & 7581 & 18043 & 5945 & 27 & 68906 \\
\hline 2004 & 7292 & 0 & 4831 & 553 & 2 & 12678 & 2004 & 35477 & 7577 & 18167 & 8317 & 37 & 69575 \\
\hline 2005 & 7277 & 0 & 5017 & 1064 & 2 & 13360 & 2005 & 40799 & 7577 & 18220 & 9918 & 60 & 76574 \\
\hline 2006 & 7685 & 0 & 5053 & 1681 & 3 & 14422 & 2006 & 43659 & 7365 & 18318 & 11722 & 180 & 81244 \\
\hline 2007 & 7692 & 0 & 5061 & 2201 & 24 & 14978 & 2007 & 47412 & 7365 & 18372 & 14820 & 750 & 88719 \\
\hline 2008 & 7767 & 0 & 5058 & 2857 & 59 & 15741 & 2008 & 47832 & 7365 & 18451 & 16555 & 3450 & 93653 \\
\hline 2009 & 8846 & 0 & 5091 & 3326 & 115 & 17378 & 2009 & 47760 & 7365 & 18505 & 19176 & 3770 & 96576 \\
\hline 2010 & 9871 & 0 & 5106 & 3796 & 134 & 18907 & 2010 & 50457 & 7450 & 18535 & 20693 & 4653 & 101788 \\
\hline 2011 & 9936 & 0 & 5535 & 4256 & 172 & 19899 & 2011 & 49786 & 7450 & 18540 & 21529 & 5501 & 102806 \\
\hline 2012 & 9360 & 0 & 5717 & 4412 & 238 & 19727 & 2012 & 49736 & 7450 & 18550 & 22789 & 6646 & 105171 \\
\hline 2013 & 8308 & 0 & 5666 & 4610 & 296 & 18880 & 2013 & 49786 & 6984 & 19094 & 22958 & 7016 & 105838 \\
\hline
\end{tabular}


third legislative package, has been commissioned by the Agency for the Cooperation of Energy Regulators (ACER) to prepare a set of network codes, in order to harmonise rules across TSOs, thereby guaranteeing an efficient transmission network management. Amongst these, the Network Code on Capacity Allocation and Congestion Management (CACM) will establish uniform interconnection capacity allocation methods to be applied in all European markets, in order to allow consistent trade and supply of electricity across borders. ACER has recommended the adoption of this code by the European Commission on $26^{\text {th }}$ May 2014 (ACER, 2014a) and is currently with the Electricity cross-border Committee.

The transmission and cross-border interconnection costs determination play an important role in market design. Cost allocation methods are usually either Flat Rate based or Flow-based. Flat rate methods, which are simple to calculate and implement, are however, unfair to generators that use less capacity and extent of the transmission lines (Galiana et al., 2003). On the other hand, flow-based costs are most commonly used due to their dependence on the capacity and extent used by each generator of the transmission lines. Explicit auctioning, where interconnector capacity is sold to the highest bidder or implicit auctioning, which integrates electricity and transmission markets and also called Market Splitting/Price Coupling, are both used across Europe (Coppens and Vivet, 2006).

To join electricity markets, several methodologies for crossborder interconnection congestion management were used in different REM. In Europe consensus has recently been achieved concerning implicit auctioning through market coupling/ splitting $^{1}$ (Glachant, 2010). Initially implemented in the Nordic countries in 1996, it was then implemented in 2006 between Belgium, France and the Netherlands, the so called trilateral market coupling (Figueiredo and Silva, 2013b). In July 2007, the Iberian spot electricity market started operation, implementing a market splitting implicit auctioning process between Portugal and Spain, which is the subject of the present study. The trilateral market coupling was then extended to Germany and Luxembourg in November 2010, creating the Central West Europe regional electricity market.

The market coupling arrangement allows the coordination of different price zones through an implicit auctioning process, increasing overall welfare in the coupled markets (Jacottet, 2012). With this arrangement, markets with lower prices export electricity to markets with higher prices through limited capacity cross-border interconnections (Meeus et al., 2009). If the interconnection capacity is large enough to accommodate the exported electricity flows (without congestion), then the price is the same in both markets (Fig. 1) otherwise, market splitting occurs and two regional market prices are cleared (Fig. 2) (EPEX, 2010). The basis of this arrangement is the calculation of the Available Transfer Capacity (ATC), which is made by the TSOs taking into account the safety and reliability of the electrical system, together with an allowable safety margin (Turvey, 2006). Therefore, import and export ATC can have different values depending on loop flows and technical constraints (Luna and Martínez, 2011). In the case of Iberia, subject

\footnotetext{
${ }^{1}$ In Weber et al. (2010) the distinction between market coupling and market splitting is clarified:

- Market splitting - markets operated by a single power exchange.

- Market coupling - markets managed through co-operation of multiple power exchanges

Both have a similar welfare optimisation algorithm behind. Therefore, the main difference is that the market coupling algorithm needs the additional complexity of a Market Coupler receiving information from multiple power exchanges (Biskas et al., 2013; EPEX, 2010; Nord Pool, 2015; OMIE, 2015).
}

of this study, the EUPHEMIA algorithm for the market coupling arrangement is implemented (OMIE, 2014). For the analysed period there was no market coupling/splitting implemented across the French-Spanish interconnection (implemented in May 2014).

The literature is vast on the discussions of the merits and issues of market splitting/market coupling. Hobbs et al. (2005) analysed the introduction of market coupling between Belgium and the Netherlands through a Cournot-Nash model, reaching the conclusion that market coupling would improve social surplus depending on existing market power of market players. Furthermore, in this same region, De Jonghe et al. (2008) found a sharp decrease of the hourly price differences after the introduction of the Trilateral Market Coupling between Belgium, France and the Netherlands, in spite of this, a reduction on price volatility could only be found in the Netherlands. Kristiansen (2007) through an empirical analysis assessed the introduction of the market coupling arrangement between East Denmark and Germany (the Kontek cable), finding a relatively low level of market splitting. Genesi et al. (2008a and 2008b) showed that market coupling would achieve an efficient cross-border interconnection capacity allocation through the solution of a set of linear programing problems. Barth et al. (2009) found that market coupling reduced the total system operation costs and the electricity prices, considering a high level of wind power deployment, through the use of a deterministic input/output model. Further models to evaluate market coupling were developed by Waniek et al. (2009) based on the simulation of the market by aiming for the maximisation of economic welfare, Kurzidem (2010) modelling imperfect competition in electricity and transmission markets, Oggioni and Smeers (2013 and 2010) and Smeers et al. (2010) with a Generalised Nash Equilibrium applied to different organisations of counter-trading activities and assuming different zonal decomposition (nodal pricing and market coupling). Meeus et al. (2009) discussed the use of locational marginal prices and the importance of price coordination, through the minimisation of the congestion rents, in order to avoid distorsion of network development incentives. The options of volume coupling versus price coupling and centralised versus decentralised approach were discussed by Glachant (2010), reaching the conclusion that decentralised price coupling, or market coupling, would be the most feasible solution. In the Italian electricity market, Pellini (2012b) found a welfare increase with the introduction of the market coupling arrangement. Biskas et al. (2013), through a Mixed-integer Linear Programming model, found better welfare gains with the implementation of a market splitting versus a market coupling arrangement. The introduction of demand side participation in the electricity markets is refered by Caramanis et al. (2010) as a means to contribute to system stability, considering renewable generation intermittency.

A study performed by Salic and Rebours (2011) did not address directly the market coupling/splitting arrangement, but assessed the contribution of day-ahead wind power generation forecasts for Germany on the net transfer capacity from Germany to France. Findings establish negative relations between the day-ahead wind power generation forecast and the day-ahead net transfer capacity. These results can suggest that with less net transfer capacity, the ATC calculated is also smaller, thus increasing market splitting probability.

The initiative denominated Price Coupling of Regions (PCR) was launched at the Florence Regulatory Forum in 2009 by three power exchanges: Nordpool, EPEX and MIBEL (Europex, 2009), to be implemented by the end of 2012. In the meantime additional members joined the initiative, APX-Endex, Belpex and GME, reaching the $2860 \mathrm{TWh} /$ year of potential electricity trading 


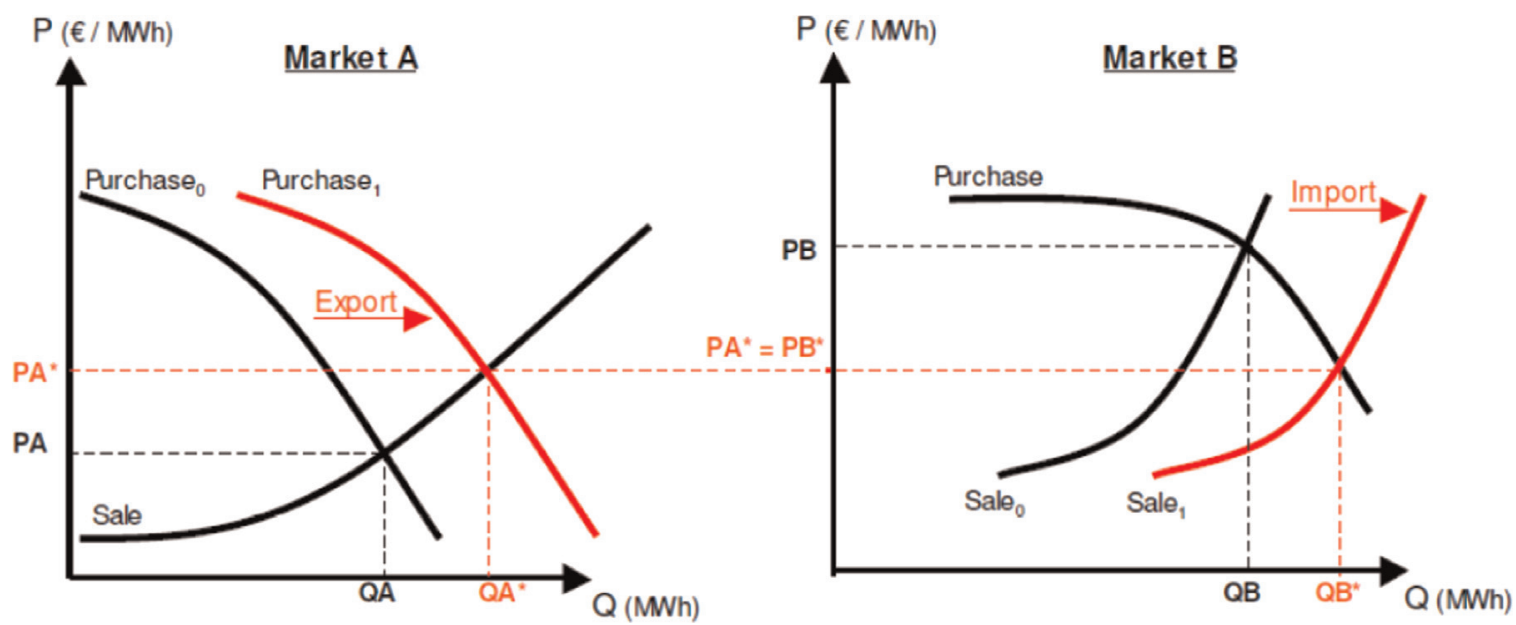

Fig. 1. Market coupling without congestion (EPEX, 2010).

(Europex, 2011) and to be fully implemented by the end of 2014. In May 2014 market coupling between Iberia, Central West Europe and Nordpool was achieved, which was one of the main objectives of the Price Coupling of Regions initiative. Finally, on $24^{\text {th }}$ February 2015 market coupling was implemented between Italy, Austria, France and Slovenia. Consequently, 19 countries are now linked improving integration of the European electricity market.

\section{Methods}

Market splitting occurs when there is congestion of cross-border interconnection. The amount of electricity flowing through a cross-border interconnection with creating congestion, thus market splitting, will depend on its capacity available for commercial trades. Moreover, if congestion occurs, then the electricity flowing across the cross-border interconnections will be constant during the duration of this same congestion. A consequence of this congestion is the separation of the spot electricity prices.

To model market splitting behaviour, the explored options were: (a) to establish a probability of occurrence, therefore assuming a binary dependent variable, or (b) to model the price difference between spot electricity markets. This later model might have specification problems due to the large number of hourly periods where the spot electricity price difference is zero. Therefore, the models pursued were based on the probability of market splitting occurrence.
Logit and nonparametric models are estimated to express the probability response of day-ahead spot electricity prices market splitting (the binary variable of market splitting occurrence assumes the value 1 if the difference of the hourly Iberian spot electricity prices is not zero and assumes the value 0 otherwise), as a function of the explanatory variables: wind, hydro, nuclear and thermal power generation, together with ATC and electricity demand.

Solar power generation is negligible in Portugal, and in Spain its size is approximately the same as nuclear power. Solar power is mostly available connected to the distribution grid, indicating an absence of online remote metering. Therefore, given its small relative share and the absence of reliable hourly data, this technology was not included in our study.

Therefore, the inputs to the model are: the wind, hydro, thermal and nuclear power generation shares, the ATC in both directions and demand in both electricity markets. The model will then provide, as an output, the probability of market splitting occurrence.

In the following sub-sections, data, logit and non-parametric model specifications are described. The use of non-parametric models in the assessment of market splitting provides a novel approach in the analysis of interconnected electricity markets.

\subsection{Data}

Hourly data for the day-ahead spot electricity prices in $€ / M W h$

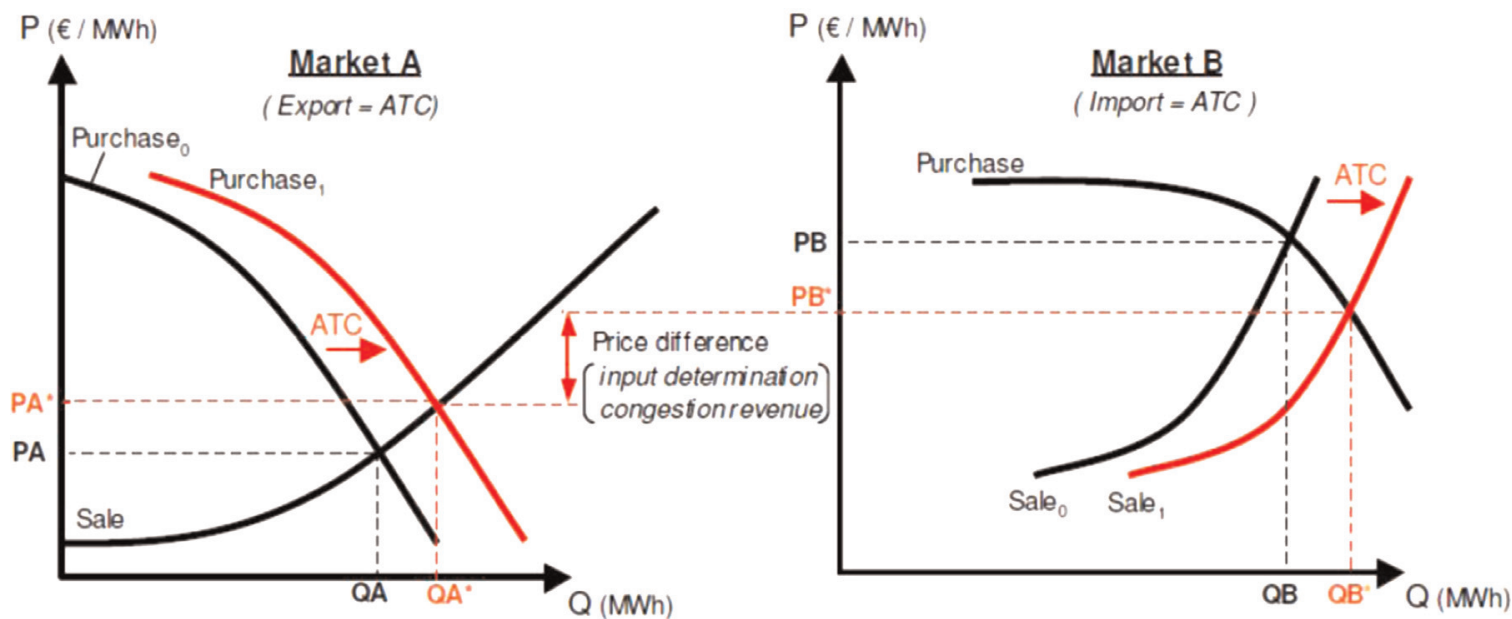

Fig. 2. Market coupling with congestion - market splitting (EPEX, 2010). 


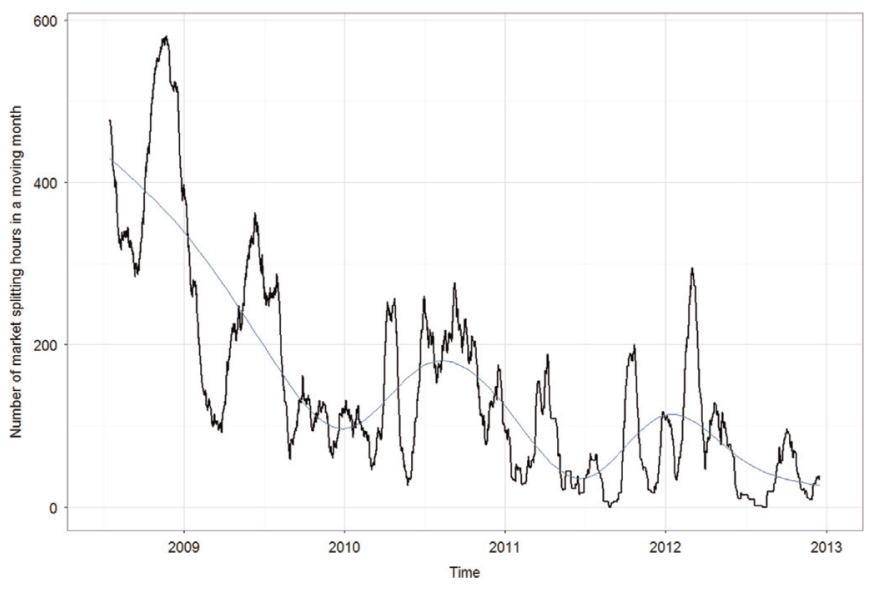

Fig. 3. Iberian market splitting evolution.

and for the ATC in MW were extracted from OMIE (OMIE, 2013), for Portugal and Spain, from 1st July 2008 until 31st December 2012. From the Transmission System Operators of both countries, hourly demand and generating data were extracted (Red Eléctrica de España, 2014; Redes Energéticas Nacionais, 2014). Additionally, installed generation capacities in both Iberian countries were obtained from Eurostat (Eurostat, 2015).

Market integration in Iberia has been demonstrated in several other studies (Figueiredo and Silva, 2013a). However, market splitting occurred in $19.1 \%$ of the observed hours within the complete data set. A similar pattern of market splitting is reported in Woo et al. (2011), between the North and West zones of Texas. In these zones, the development of wind power is equally relevant. It is to highlight that, with the renewable-energy credit trading programme target for 2015 (5.88 GW) already surpassed, wind power generation installed capacity achieved $7.5 \mathrm{GW}$ in 2009. In Iberia, as shown in Fig. 3, the share of market splitting in a moving month has, somehow, decreased over time presenting oscillations with a maxima in 2012 of 294 hours in a moving month. Specifically, peaks observed in 2012 and 2013 occur in March, typically a month with high availability of wind and hydro generation.

The Portugal-Spain electrical interconnection currently consists of eight HV lines with a maximum interconnection capacity of $2400 \mathrm{MW}$ (Red Eléctrica de España, 2012). A new interconnection line between Tavira and P. Guzman is being constructed (to be concluded by REE on the Spanish side) and another new line is forecast to be in service in 2015 between V. Fria and $O$ Covelo, which with several other internal line reinforcements will allow the completion of the interconnection capacity between Portugal and Spain of $3000 \mathrm{MW}$, essential for the joint Iberian electricity market MIBEL (Redes Energéticas Nacionais, 2013). The existing maximum interconnection of $2400 \mathrm{MW}$ is $2.7 \%$ of the Spanish and $12.7 \%$ of the Portuguese total installed capacities, or $5.4 \%$ of the Spanish and $25.5 \%$ of the Portuguese maximum demand. Concerning the ATC (Fig. 4), the increase in interconnection capacity between the two Iberian countries is visible, with the last improvement being observed in mid-2012. It is also of note that ATC limitations are more often observed in the direction from Spain to Portugal. A possible explanation is that the calculation of the ATC made by REE includes safety factors resulting from the relative larger size of the Spanish electricity system, taking into account network security constraints.

Wind power generation has significant variability in both Iberian countries, without any evident seasonal pattern, meaning that wind power generation might be present throughout all weather seasons. This is not the case with hydro power generation, where some seasonality can be found. It is of note that in spite of the larger size generation in Spain, Portugal has higher shares of both wind power and hydro power generation.

Both thermal power generation and respective shares are larger in Spain, with a slight tendency to decrease with time. Again, the different scales of the Portuguese and Spanish electricity markets are a natural consequence of the countries asymmetric dimensions.

Nuclear generation is only present in Spain, evidencing both stable installed capacity and generation share, within the period herein considered. Currently, no plans exist for new nuclear power capacity, apart from some plant upgrades and life extension. There are seven nuclear power plants operating, three of them licenced up to 2020, another three up to 2021 and the last up to 2024 (World Nuclear Association, 2015).

Summary statistics for the time series are presented in Table 2.
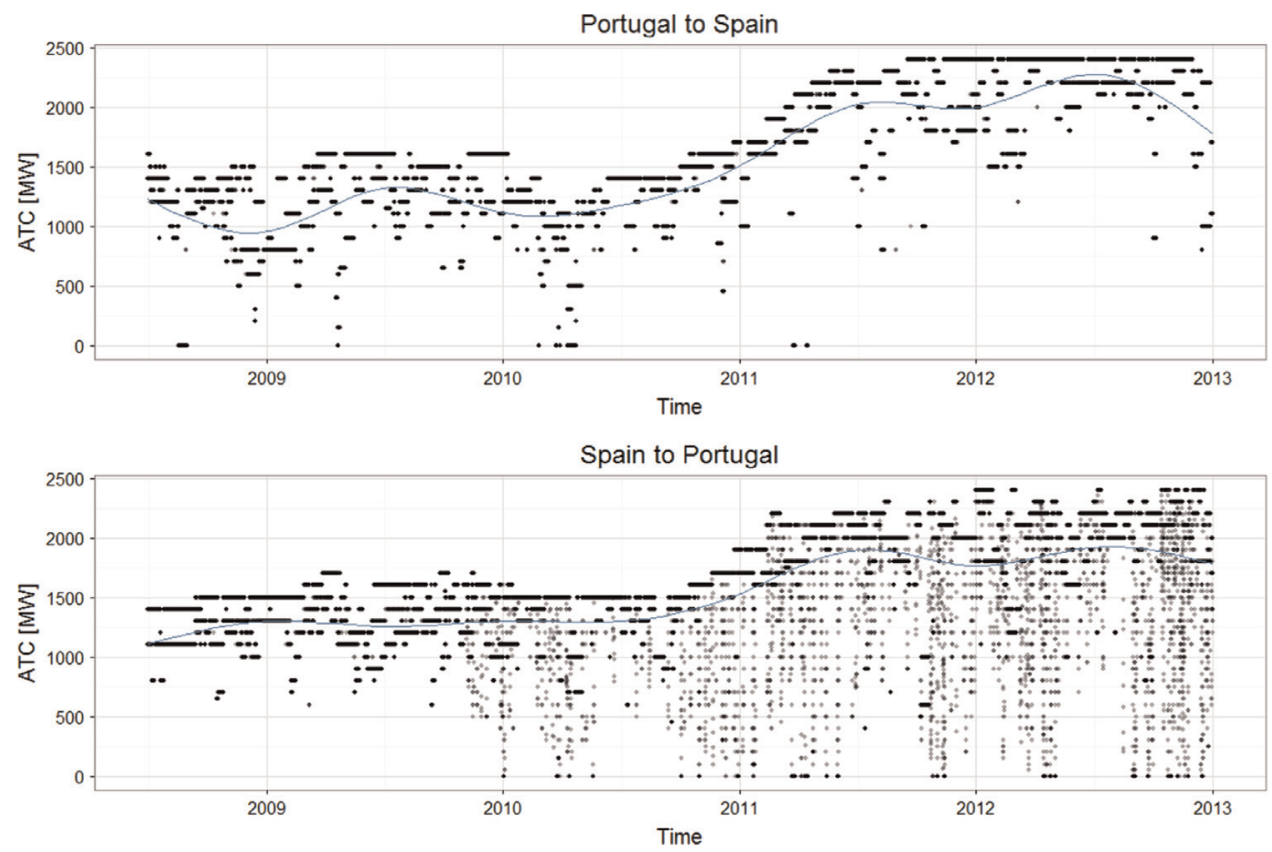

Fig. 4. Available transfer capacities in Iberia. 
Table 2

Time series summary statistics.

\begin{tabular}{|c|c|c|c|c|c|c|c|}
\hline & $\begin{array}{l}\text { Price PT } \\
\text { [€/MWh] }\end{array}$ & $\begin{array}{l}\text { Price ES } \\
\text { [€/MWh] }\end{array}$ & $\begin{array}{l}\text { Price difference (PT-ES) } \\
\text { [€/MWh] }\end{array}$ & $\begin{array}{l}\text { ATC PT-ES } \\
{[\mathrm{MW}]}\end{array}$ & $\begin{array}{l}\text { ATC ES-PT } \\
{[\mathrm{MW}]}\end{array}$ & $\begin{array}{l}\text { Demand PT } \\
\text { [MWh] }\end{array}$ & $\begin{array}{l}\text { Demand ES } \\
\text { [MWh] }\end{array}$ \\
\hline Mean & 46.687 & 45.549 & 1.138 & -1542.638 & 1528.993 & 5749.859 & 29165.640 \\
\hline Median & 46.400 & 45.910 & 0.000 & -1500.000 & 1500.000 & 5734.602 & 29311.830 \\
\hline Maximum & 180.300 & 145.000 & 136.300 & 0.000 & 2400.000 & 9383.980 & 44273.830 \\
\hline Minimum & 0.000 & 0.000 & -47.460 & -2400.000 & 0.000 & 3406.955 & 17687.000 \\
\hline Std. Dev. & 15.789 & 15.482 & 4.448 & 550.142 & 461.404 & 1078.157 & 5227.109 \\
\hline Skewness & -0.004 & -0.144 & 3.983 & 0.178 & -0.379 & 0.258 & 0.118 \\
\hline Kurtosis & 4.020 & 3.958 & 61.218 & 2.615 & 3.195 & 2.286 & 2.115 \\
\hline Jarque-Bera & 1709.909 & 1644.498 & 5677558.000 & 451.979 & 1007.788 & 1276.854 & 1381.278 \\
\hline Probability & 0 & 0 & 0 & 0 & 0 & 0 & 0 \\
\hline \multirow[t]{4}{*}{ Observations } & 39464 & 39464 & 39464 & 39464 & 39464 & 39464 & 39464 \\
\hline & Wind & Wind & Hydro gen PT & Hydro gen & Thermal & Thermal & Nuclear \\
\hline & gen PT & gen ES & & ES & gen PT & gen ES & gen ES \\
\hline & [MWh] & [MWh] & [MWh] & [MWh] & [MWh] & [MWh] & [MWh] \\
\hline Mean & 974.343 & 4672.579 & 924.694 & 2466.898 & 1402.330 & 11213.700 & 6347.269 \\
\hline Median & 775.398 & 4137.833 & 763.825 & 2257.000 & 1438.300 & 11075.000 & 6404.667 \\
\hline Maximum & 3715.670 & 16469.170 & 3904.475 & 11398.670 & 3731.750 & 25323.500 & 8028.833 \\
\hline Minimum & 5.313 & 0.000 & -1038.700 & -3381.000 & -31.500 & 0.000 & 0.000 \\
\hline Std. Dev. & 752.585 & 2743.402 & 943.465 & 2251.771 & 589.611 & 4443.246 & 878.241 \\
\hline Skewness & 0.964 & 0.799 & 0.643 & 0.500 & 0.073 & 0.171 & -0.618 \\
\hline Kurtosis & 3.254 & 3.158 & 2.801 & 3.105 & 3.126 & 2.563 & 2.774 \\
\hline Jarque-Bera & 6220.696 & 4240.083 & 2783.354 & 1661.358 & 60.802 & 506.093 & 2596.882 \\
\hline Probability & 0 & 0 & 0 & 0 & 0 & 0 & 0 \\
\hline Observations & 39464 & 39464 & 39464 & 39464 & 39464 & 39464 & 39464 \\
\hline
\end{tabular}


Skewness and kurtosis values indicate that all price time-series have non-normal distribution, which is confirmed by Jarque-Bera statistic rejection of the null for normal distribution testing.

\subsection{Logit model estimation}

The estimated models aim to provide indications about the behaviour of the market splitting arrangement in the Iberian spot electricity markets, considering the mix of the main available generation technologies, ATC and Demand in these same markets.

The market splitting probability model used is:

$P($ Split $=1 \mid X)=P($ Split* $>0 \mid X)=P(X \beta+e>0 \mid X)$,

where $X$ is a matrix of explanatory variables and $e$ is the error term that is an independently distributed variable independent from $X$ following the standard logistic distribution ${ }^{2}$, from which we obtain,

$P(e>-X \beta \mid X)=1-P(e \leq-X \beta \mid X)=1-\Lambda(-X \beta)=\Lambda(X \beta)$,

where

$\Lambda(X \beta)=\frac{\exp (X \beta)}{1+\exp (X \beta)}$.

The probability of market splitting is modelled as a function of explanatory variables representing thermal, nuclear, hydro and wind power generation. The other explanatory variables used consist of the demand of each country and the ATC between both spot electricity markets. The former expresses the ability of the country to consume the electricity produced and the latter expresses the ability to export the electricity generated.

Following the concept of wind power penetration level or generation share (Jónsson et al., 2010), we have expanded it to the remainder of the generation technologies considered in the model.

The estimated model associated to the Split latent variable is then:

$$
\begin{aligned}
\text { Split* } * & \beta_{0}+\beta_{1} \cdot \frac{W_{P T}}{D_{P T}}+\beta_{2} \cdot \frac{W_{E S}}{D_{E S}}+\beta_{3} \cdot \frac{H_{P T}}{D_{P T}}+\beta_{4} \cdot \frac{H_{E S}}{D_{E S}}+\beta_{5} \cdot \frac{T_{P T}}{D_{P T}}+\beta_{6} \\
& \cdot \frac{T_{E S}}{D_{E S}}+\beta_{7} \cdot \frac{N_{E S}}{D_{E S}}+\beta_{8} \cdot A T C_{P T-E S}+\beta_{9} \cdot A T C_{E S-P T}+\beta_{10} \\
& \cdot D_{P T}+\beta_{11} \cdot D_{E S}+e,
\end{aligned}
$$

,where $W_{P T}$ and $W_{E S}$ are the hourly wind power generation in Portugal and Spain, respectively; $H_{P T}$ and $H_{E S}$ are the hourly hydro power generation in Portugal and Spain, respectively; $T_{P T}$ and $T_{E S}$ are the hourly thermal power generation in Portugal and Spain, respectively; $N_{E S}$ is the hourly nuclear power generation in Spain; $A T C_{P T-E S}$ and $A T C_{E S-P T}$ the hourly ATC for both directions of the interconnections between Portugal and Spain; and $D_{P T}$ and $D_{E S}$ the hourly electricity demand in Portugal and Spain, respectively.

\subsection{Non-parametric model estimation}

Non-parametric models do not require parametric assumptions for the underlying data generation process (Pagan and Ullah, 1999). Moreover, data has the required information allowing for the model estimation through kernel methods, consisting simply of a weighting function. Non-parametric models are an alternative to parametric models, where specification issues are found to reject or at least to question such a model. Bandwidth choice is

\footnotetext{
${ }^{2}$ The option was to apply the logit model as a binary response model, due to the fact that the probit model latent error does not follow a normal distribution (Wooldridge, 2003).
}

crucial in these methods and the data-driven bandwidth choice can present a quite demanding computational challenge, due to the nature of the kernel methods (Racine, 2007). With the evolution of computer processing speed, this situation is improving and namely the use of parallel processing presents as the most viable solution when using large datasets, as it is the case in this study. Further detailed information about non-parametric models can be found in Hayfield and Racine (2008) and Racine (2007).

Our non-parametric models were developed in $\mathrm{R}$ (The $\mathrm{R}$ Foundation for Statistical Computing, 2014) using the "np" package for non-parametric kernel estimation (Hayfield and Racine, 2008). The non-parametric models developed further expand on the indications provided by the logit models. These are expected to provide additional performance and details on the behaviour of the market splitting arrangement in the Iberian spot electricity markets, avoiding the specification issues described.

Models were implemented in R: (i) without parallel processing, using the "rule of thumb" for bandwidth selection, and (ii) with parallel processing, using "likelihood cross-validation", taking advantage of the npRmpi routines for bandwidths calculation and model estimation. Depending on the type of variable considered, different types of univariate kernels are used to obtain the generalised product kernels. The continuous variables were modelled by using a second-order Gaussian kernel function:

$K(z)=\frac{e^{\left(-\left(\frac{x_{i-x}}{h}\right)^{2} / 2\right)}}{\sqrt{2 \pi}}$,

and the categorical variables are modelled by using the kernel function proposed by Aitchison and Aitken (1976):

$l\left(X_{i}, x, \lambda\right)=\left\{\begin{array}{ll}1-\lambda, & \text { if } X_{i}=x \\ \frac{\lambda}{c-1}, & \text { otherwise }\end{array}\right.$,

where $c$ is the number of outcomes in $x$ and $\lambda \in[0,(c-1) / c]$.

Both $h$ and $\lambda$ are the bandwidths respectively for the continuous variables and for the categorical variables kernel functions. Being the most crucial aspect of non-parametric modelling, model bandwidths were calculated through several different methods in order to compare and select the most adequate for the intended purpose (Okumura and Naito, 2004). For the models expressing the probability of market splitting, two methods for bandwidth selection were used:

- "Rule of Thumb" $h=1.06 \cdot \sigma \cdot n^{-1 /(2 P+l)}$

where $\sigma$ is the $\min (\hat{\sigma}$, interquartile range/1.349), $n$ is the number of observations, $P$ is the order of the kernel and $l$ the number of continuous variables;

$$
\begin{aligned}
& \text { - Likelihood crossvalidation } \mathcal{L} \\
& =\sum_{i=1}^{n} \log \left[\frac{1}{(n-1) h} \sum_{j=1, j \neq i}^{n} K\left(\frac{X_{j}-x}{h}\right)\right],
\end{aligned}
$$

where $h$ is selected by maximising the log likelihood function.

Similar to the logit models specified, the explanatory variables are the wind, hydro, thermal and nuclear power generations, together with the ATC and demand in each market, all of them continuous variables. The variable representing market splitting is categorical. Models were estimated with bandwidths calculated with both selection methods, considering the same data set from 1st July 2008 until 31st December 2012. In Table 4 results for the bandwidth calculation and model performance are presented for both estimated models. 


\section{Results}

Results and performance of the logit and non-parametric models are described in the following sub-sections. The use of non-parametric models is demonstrated to provide better model performance as shown below in Section 3.2.

\subsection{Logit model results}

In the estimated model all coefficients are statistically significant $(p<0.01)$ with the exception of the hydro generation share in Spain (Table 3). The "Neglected Heterogeneity" specification issue might have an influence on the coefficient estimates causing an underestimation of the effects. However relative effects of the explanatory variables can still be extracted (Mood, 2009; Wooldridge, 2010). An accuracy of 0.8257 was found for the considered model $^{3}$, with a McFadden pseudo $R$-square of 0.240 (Table 3).

Another specification issue present in the estimated model is the heteroskedasticity of the error term, as found according to the Breusch-Pagan test performed (Table 3). In this case the error term does not have a constant variance and following Davidson and Mackinnon (2004), even if the model used is the logit, it is reasonable to consider the alternative specification:

$P($ Split $=1 \mid X)=\Lambda\left(\frac{X \beta}{\exp \left(X_{\gamma}^{\prime}\right)}\right)$,

where $X^{\prime}$ is a matrix of explanatory variables belonging to the original information set and $\gamma$ a vector of parameters to be estimated. The market splitting probability is then not only dependent on the original regression function, but also on a skedastic function. The heteroskedasticity correction variables for the skedastic function were selected according to model performance. As seen in Table 3, the coefficients for the selected variables in the skedastic function (wind and hydro power generation shares, both in Portugal and Spain) are all statistically significant $(p<0.01)$. The heteroskedasticity corrected model achieved a better McFadden pseudo R-squared (0.275) and a slightly better accuracy, sensitivity and specificity (Table 3). For simplicity, other estimated models are not herein presented.

These results lead to the necessity of deepening our analysis about market splitting behaviour, through the estimation of nonparametric model as presented in the following Section.

\subsection{Non-parametric model results}

With higher accuracy, sensitivity and specificity, the nonparametric models herein estimated have better performance than the logit and do not suffer from related specification issues, as the ones described in Section 2.2. In particular, the performance of the estimated model with the bandwidth selected by likelihood crossvalidation is quite superior to all other estimated models, as seen in Table $4 .{ }^{4}$ With a sensitivity of 0.9135 and a specificity of 0.9900 the likelihood cross-validation non-parametric model outperforms all other estimated models. The likelihood cross-validation bandwidth calculation method obtains in general smaller bandwidths, which will create more complex shapes as is later shown in Section 4

\footnotetext{
${ }^{3}$ Confusion matrices are available from authors upon request. A confusion matrix is a performance measure used to evaluate probability response models. It compares for the binary dependent variable the observed values with the predicted results from the model. Further description of this performance measure can be found in Bontemps et al. (2011).

${ }^{4}$ Confusion matrices are available from authors upon request.
}

Table 3

OMIE market splitting logit model.

Dependent variable: Market Split

Data: 1st of July 2008 to 31st of December 2012

Coefficients (binomial model with logit link):

No het. Correction Het. Correction

\begin{tabular}{|c|c|c|c|c|}
\hline c & 3.157 & $* * * *$ & 7.12 & $* * * *$ \\
\hline Wind share PT & -5.028 & $* * * *$ & -13.36 & $* * k * *$ \\
\hline Wind share ES & 6.588 & $* * *$ & 12.66 & $* * * *$ \\
\hline Hydro share PT & -4.925 & $* * *$ & -12.91 & $* * * *$ \\
\hline Hydro share ES & 0.2876 & & -6.683 & $* * * *$ \\
\hline Thermal share PT & -4.744 & $* * * *$ & -8.901 & $* * * *$ \\
\hline Thermal share ES & 5.343 & $* * *$ & 8.089 & $* * * *$ \\
\hline Nuclear share ES & 3.367 & $* * *$ & 3.272 & $* * * *$ \\
\hline ATC PT to ES & -0.000979 & $* * * *$ & -0.001415 & $* * * *$ \\
\hline ATC ES to PT & -0.002207 & $* * * *$ & -0.004095 & $* * * * *$ \\
\hline Demand PT & 0.0002289 & $* * * *$ & 0.0003794 & $* * * *$ \\
\hline Demand ES & -0.00008922 & $* * * *$ & -0.000125 & $* * * *$ \\
\hline \multicolumn{5}{|c|}{ Latent scale model coefficients (with log link): } \\
\hline Wind share PT & & & 1.5167 & 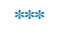 \\
\hline Wind share ES & & & -0.7004 & $* * * *$ \\
\hline Hydro share PT & & & 1.1257 & $* * * * *$ \\
\hline Hydro share ES & & & 3.2242 & $* * * *$ \\
\hline \multicolumn{5}{|c|}{$\begin{array}{l}\text { Studentized Breusch-Pagan test } \\
\text { data: ms.logit }\end{array}$} \\
\hline \multicolumn{5}{|c|}{$\mathrm{BP}=6096.314, \mathrm{df}=11, p$-value $<2.2 \mathrm{e}-16$} \\
\hline & No het. Correction & & Het. Correctior & \\
\hline \multicolumn{5}{|c|}{ McFadden pseudo R-squared: } \\
\hline & \multicolumn{2}{|c|}{$0.2403994(\mathrm{df}=12)$} & \multicolumn{2}{|c|}{$0.2745606(\mathrm{df}=16)$} \\
\hline Accuracy (CCR) & \multirow{2}{*}{\multicolumn{2}{|c|}{0.8257}} & \multicolumn{2}{|c|}{0.8332} \\
\hline Sensitivity (TPR) & & & \multicolumn{2}{|l|}{0.3993} \\
\hline Specificity (SPC) & \multicolumn{2}{|l|}{0.9496} & \multicolumn{2}{|l|}{0.9489} \\
\hline
\end{tabular}

*** Significant at $1 \%$ level.

Table 4

OMIE market splitting non-parametric model

Dependent variable: Market Split

Bandwidth Type: Fixed

Conditional density data (39464 observations, 12 variable(s))

(1 dependent variable(s), and 11 explanatory variable(s))

Data: 1st of July 2008 to 31st of December 2012

Unordered Categorical Kernel Type: Aitchison and Aitken

\begin{tabular}{lll}
\hline $\begin{array}{l}\text { Bandwidth Selection } \\
\text { Method: }\end{array}$ & Rule of Thumb & $\begin{array}{l}\text { Likelihood cross- } \\
\text { validation } \\
\text { Bandwidth: }\end{array}$ \\
\hline Market Split & 0 & 0.009525335 \\
Wind share PT & 0.06602877 & 0.04218351 \\
Wind share ES & 0.05050762 & 0.02516179 \\
Hydro share PT & 0.07660497 & 0.09979179 \\
Hydro share ES & 0.03462729 & 0.03768847 \\
Thermal share PT & 0.05096986 & 0.03847238 \\
Thermal share ES & 0.06278519 & 0.0230787 \\
Nuclear share ES & 0.02663741 & 0.02196849 \\
ATC PT to ES & 287.7722 & 46.59403 \\
ATC ES to PT & 232.6589 & 164.1666 \\
Demand PT & 563.9704 & 423.8871 \\
Demand ES & 2734.236 & 2419.506 \\
Continuous Kernel Type: & Second-Order Gaussian & \\
\hline Bandwidth Selection & Rule of Thumb & Likelihood cross- \\
Method: & & validation \\
\hline Accuracy (CCR) & 0.9058 & 0.9739 \\
Sensitivity (TPR) & 0.6084 & 0.9135 \\
Specificity (SPC) & 0.9851 & 0.9900 \\
\hline
\end{tabular}

The better performance of the non-parametric model is also observed in Fig. 5, where the observed and the fitted number of market splitting hours are shown for a rolling month in the 


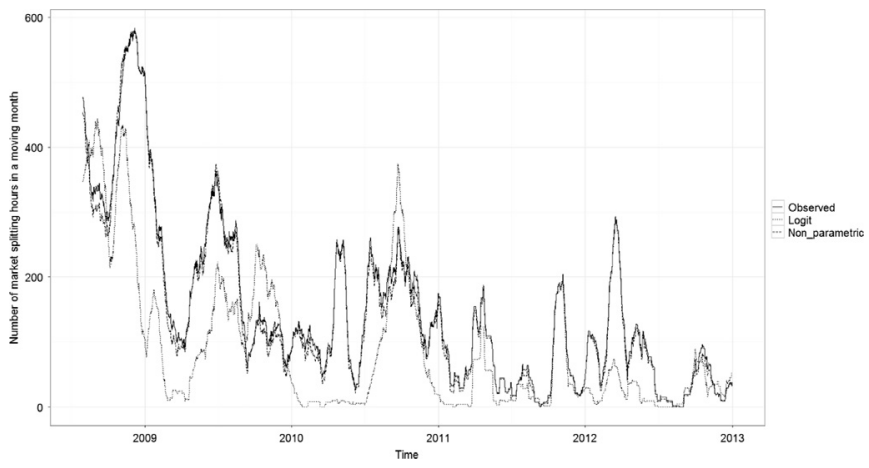

Fig. 5. Iberian market splitting evolution.

considered period, for both the heteroskedasticity corrected logit model and the non-parametric model with the bandwidth selected by likelihood cross-validation.

Logit - No correction for heteroskedasticity

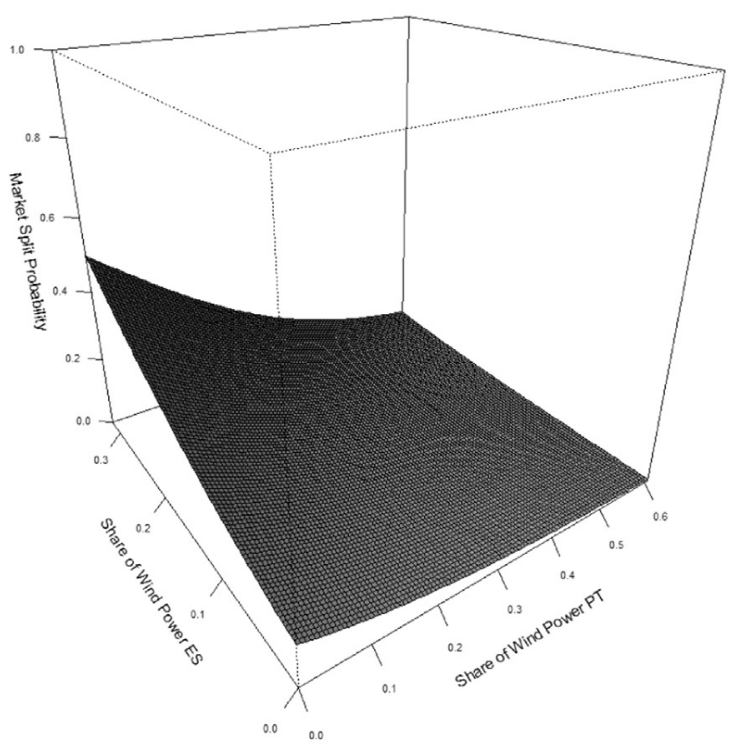

Non-parametric - Rule-of-thumb Bandwidth

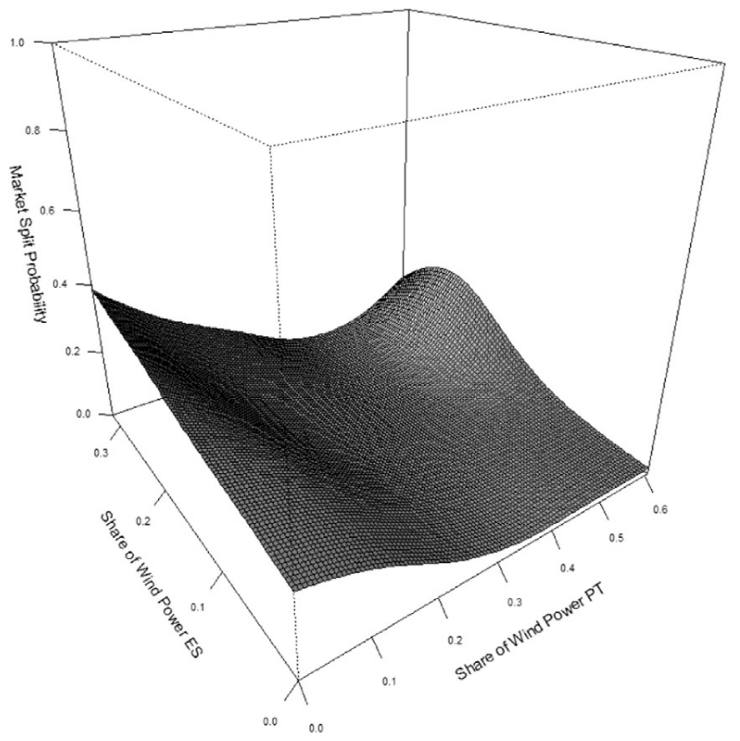

\section{Discussion}

In Table 3 the reader can find marginal effects for both logit models. Between the logit models, in-sample performance was slightly better with the heteroskedasticity correction. However, as already described, non-parametric models outperform logit, both with better performance and without the known specification issues (Table 4). In order to ease interpretation, 3D probability plots are shown and analysed for all estimated models, as follows.

\subsection{Wind power generation}

Results from the models express that market splitting probability increases generally when there is an increase of wind power generation share. Market splitting probability is more responsive to the Spanish wind power generation share, whilst there is almost no influence of the Portuguese wind power generation share (Fig. 6). This can be explained by having low marginal cost

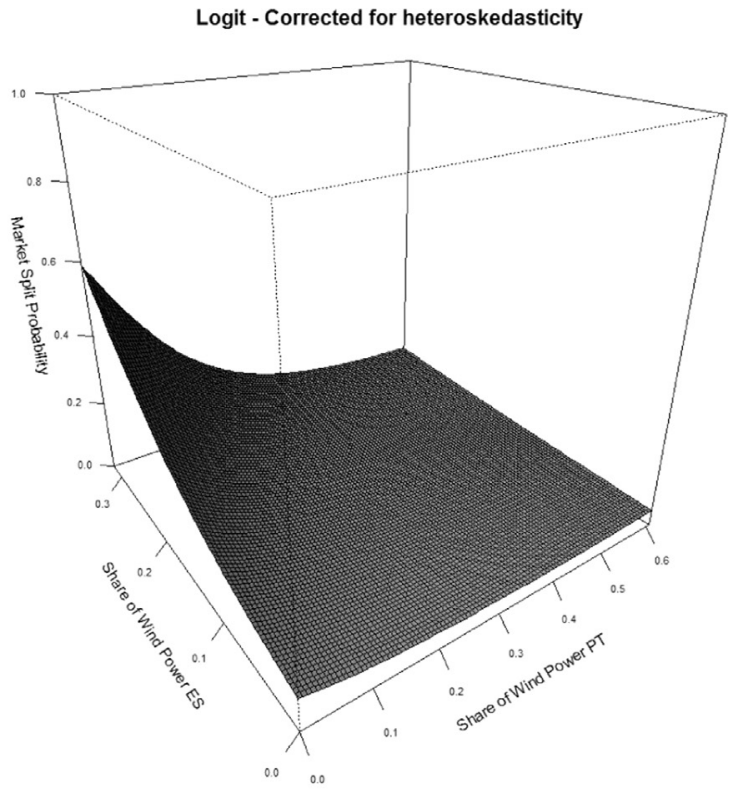

Non-parametric - Likelihood Cross-validation Bandwidth

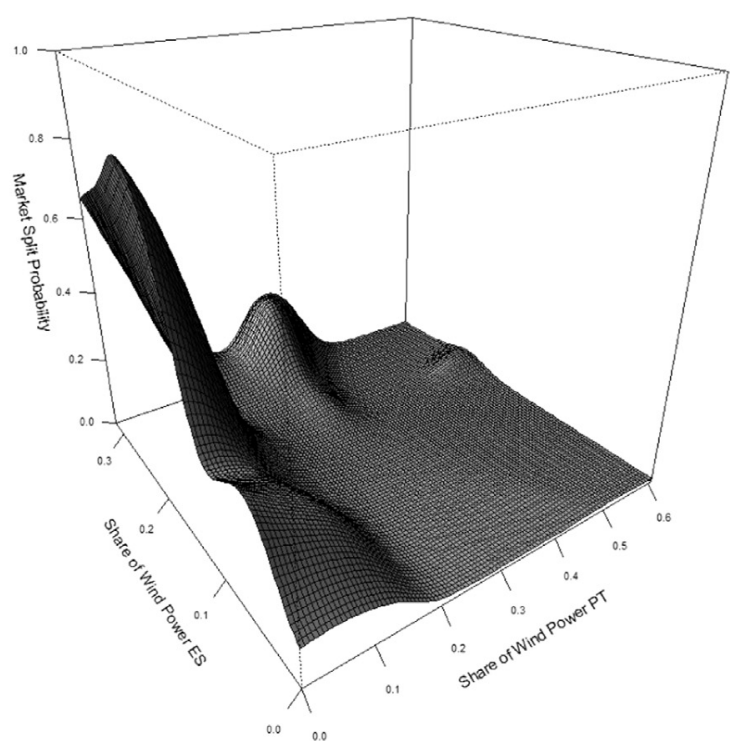

Fig. 6. Predicted probability response to wind power generation share. 
Logit - No correction for heteroskedasticity

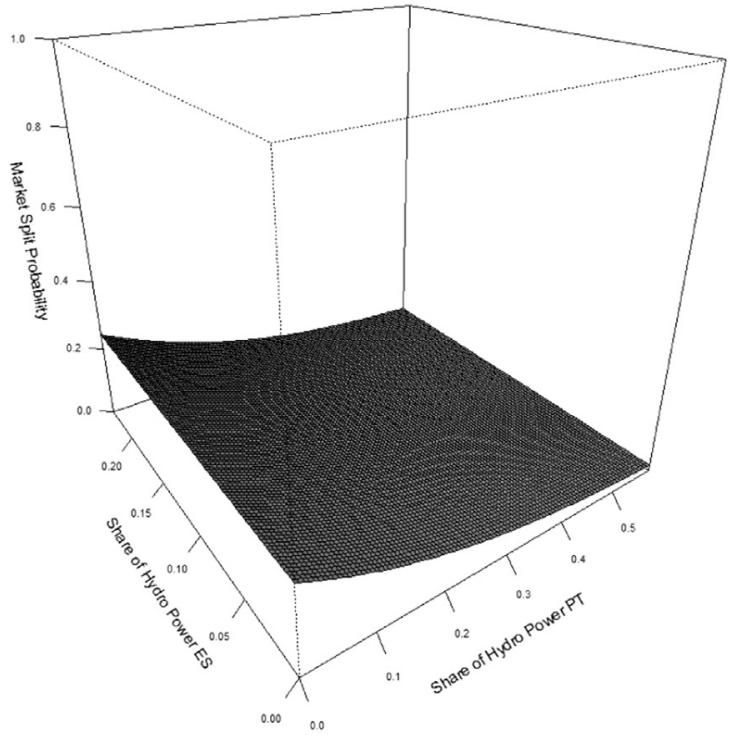

Non-parametric - Rule-of-thumb Bandwidth

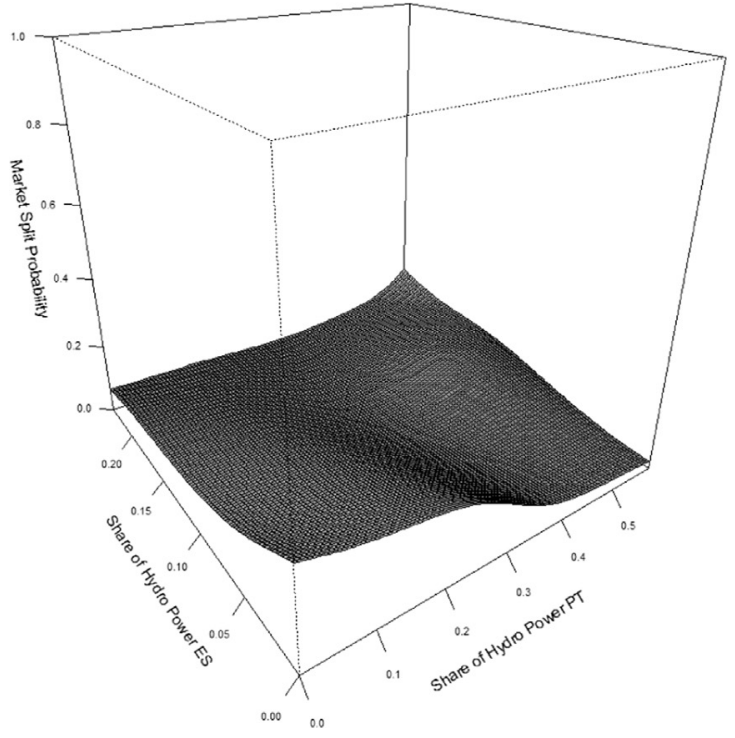

Logit - Corrected for heteroskedasticity

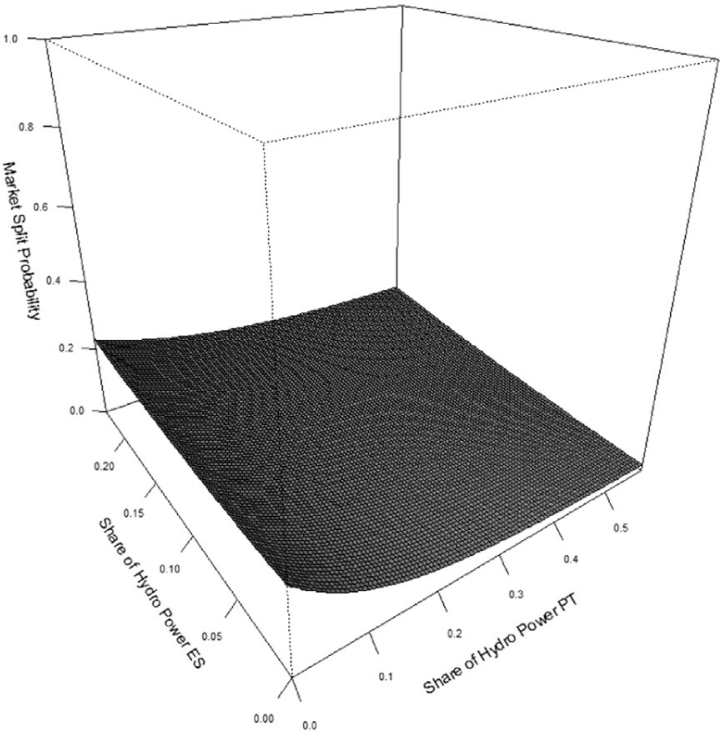

Non-parametric - Likelihood Cross-validation Bandwidth

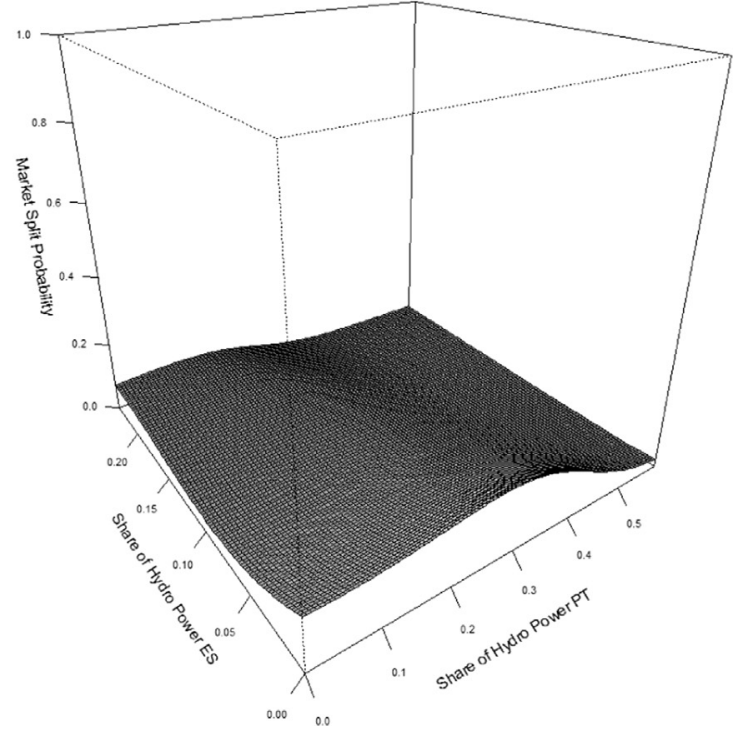

Fig. 7. Predicted probability response to hydro power generation share.

electricity available to flow across the border, mainly from Spain to Portugal due to the larger installed capacity available of wind power generation in this country. The non-parametric model provides the additional information that there is a slight market splitting probability increase when both the Spanish and Portuguese wind power generation shares are high. This fact can occur not only due to the congestion of the interconnections with low marginal cost electricity (there is low marginal cost electricity on both sides of the border), but also due to some degree of decrease in ATC calculated by the TSOs for grid security reasons; thus increasing market splitting probability. This market splitting probability increase changes when the bandwidth decreases, obtaining a better fit in the case of likelihood cross-validation as seen in Table 4.

In the case of increasing wind power generation in Spain, but not in Portugal, the market splitting probability is dramatically high. Available low price electricity in Spain congests the interconnections, however with increasing wind power generation in
Portugal there is a system balance decreasing market split probability. The asymmetry between the Portuguese and Spanish probability response behaviour is here evident due to the difference in wind power installed capacities.

\subsection{Hydro power generation}

As previously described, there is a significant share of hydro power installed generation in Portugal, which if unavailable due to a dry year and in the absence of a stable low price electricity such as nuclear, creates a significant internal supply shortage. This will then be supressed by electricity import flows from Spain, creating interconnections congestion, thereby explaining the increasing market splitting probability (Fig. 7). This behaviour is not observed in Spain in the logit models, but in the non-parametric models the additional information provided shows a similar behaviour, however not as steep, probably due to its bigger electrical system size and available nuclear power generation, which supplies a base of 
Logit - No correction for heteroskedasticity

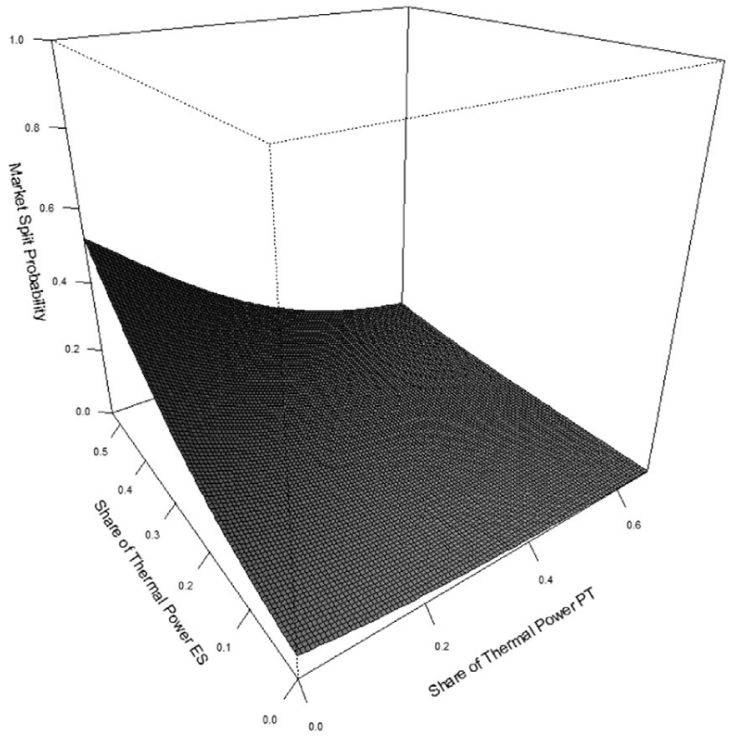

Non-parametric - Rule-of-thumb Bandwidth

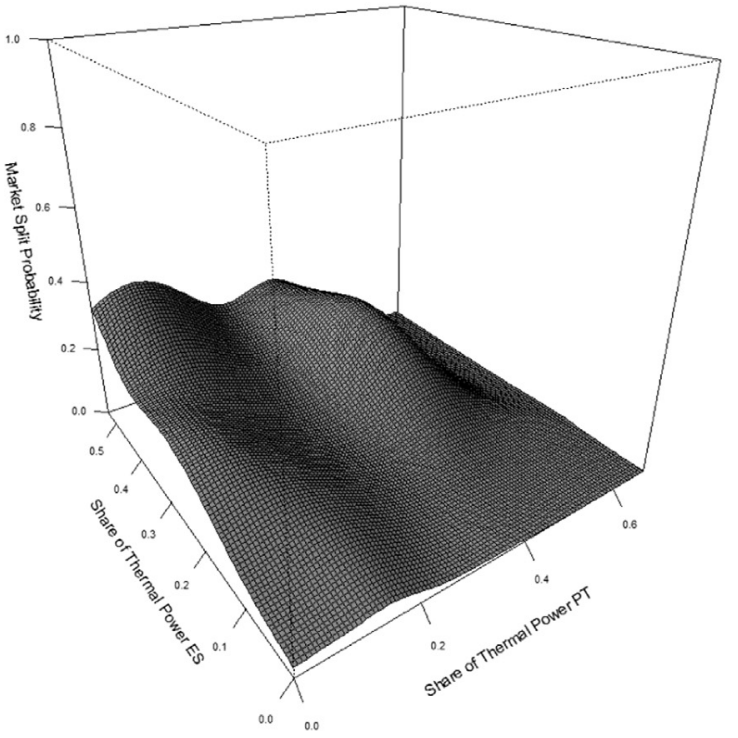

Logit - Corrected for heteroskedasticity

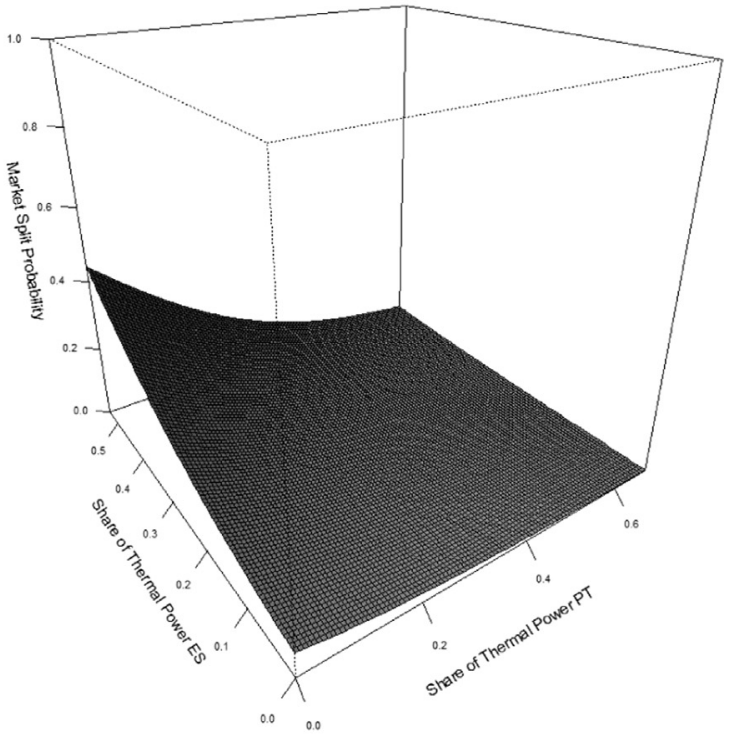

Non-parametric - Likelihood Cross-validation Bandwidth

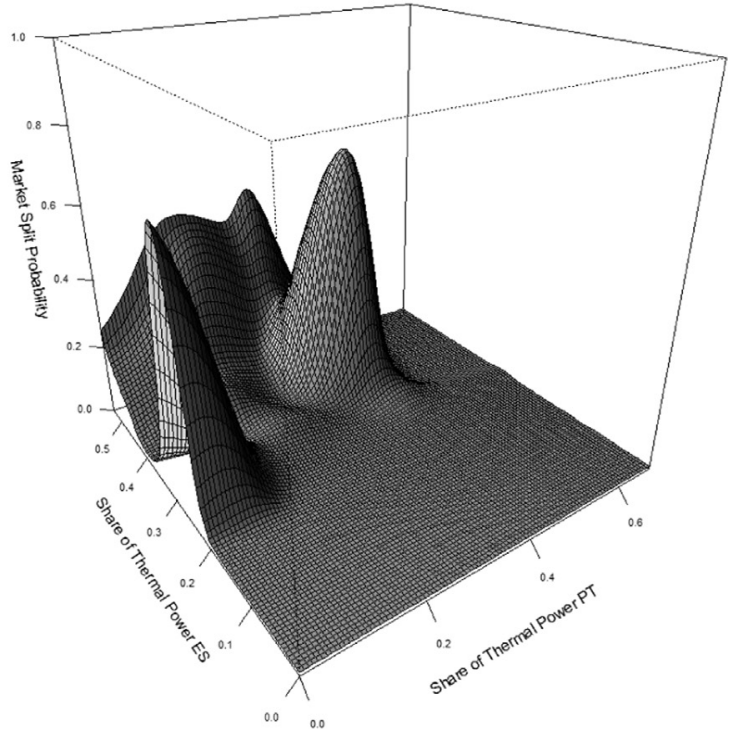

Fig. 8. Predicted probability response to thermal power generation share.

low price electricity. Furthermore, the existing hydro pump storage capacities improves the transmission grid balancing ability and allows the use of surplus renewable generation, thus decreasing cross-border transmission congestion and market splitting probability.

\subsection{Thermal power generation}

Decreasing thermal power generation share in Portugal might occur when there is a high availability of renewable resources, having high shares of wind and hydro power generation. This can create a scenario of low marginal cost electricity export from Portugal to Spain, with the increasing probability of interconnection congestion, thus market splitting. It is more evident when the thermal power generation share in Spain is high, due to its relative high marginal cost, thereby creating arbitrage between markets (Fig. 8). The peaks observed in the likelihood cross-validation bandwidth non-parametric model do not have a clear explanation, but are in the nature of these models due to the use of smaller bandwidths, capturing additional detail and allowing for better model performance (Table 4).

With increasing renewable generation share, thermal generation will be driven out of the merit order, having the remaining role of reserve capacity for balancing and system stability purposes. Therefore, the influence of thermal power generation on market splitting probability will remain low.

\subsection{Nuclear power generation}

Nuclear power generation is bid into the spot electricity markets at low marginal costs due to its inflexible operational characteristics. It is normal for nuclear power generation to be at the base of the generation mix, together with other low marginal cost technologies, like renewables or combined heat and power (CHP) plants. Therefore, with a higher share of nuclear power generation, more expensive technologies like combined cycle power plants, 

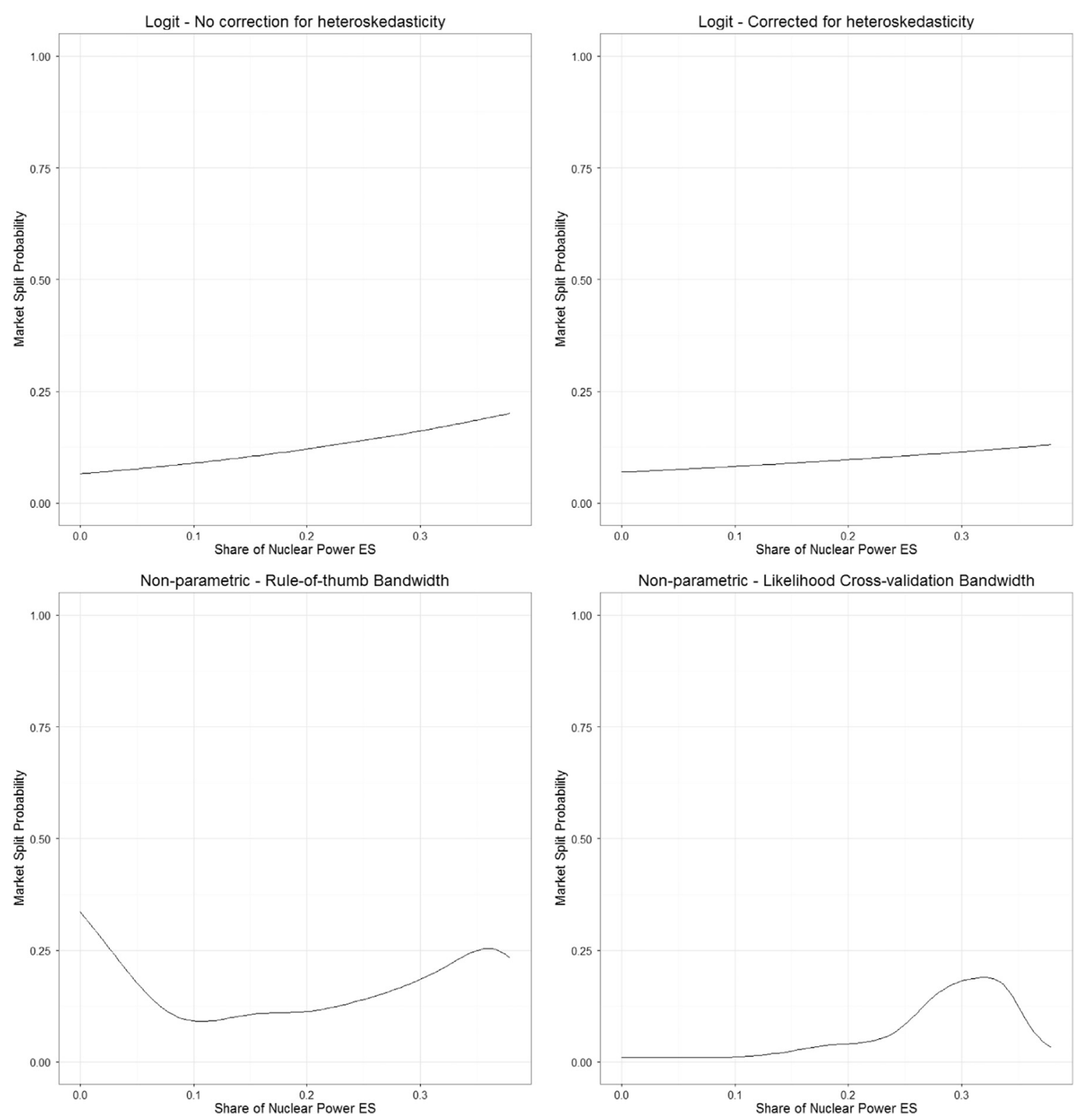

Fig. 9. Predicted probability response to nuclear power generation share.

currently last in the merit order, will be driven out of the market and the spot electricity price will decrease. In Iberia, nuclear power generation is only present in Spain, which will tend to increase exporting electricity flows to Portugal, increasing market splitting probability.

In this case the lower likelihood cross-validation bandwidth applied to the non-parametric model, changes the shape of the probability response to nuclear power generation, maintaining however the same overall increasing tendency (Fig. 9).

Depending on the policy followed, nuclear power in Spain might decrease after the decommissioning of the existing operating plants. This might occur after 2020 unless licences are extended and life extension programmes are performed. Therefore, the contribution of nuclear power for market splitting in the future should be reduced.

\subsection{Available transfer capacity}

Market splitting probability is seen to decrease with increasing ATC (allowing higher flows of electricity between markets), as one could expect by the definition of the market splitting concept (Fig. 10). Increasing ATC means that more electricity can flow through the interconnection and, consequently, saturation or congestion of the interconnection is harder to achieve. Furthermore, market splitting probability decreases. This behaviour is shown with both logit and non-parametric models, however the characteristics of the latter give a more complex probability response shape.

The complex shape captured by the non-parametric models, in spite of the difficulty in explaining it, gives detailed information and a better model performance is observed (Table 4). The increase in sensitivity to 0.9 is noteable in the likelihood cross-validation bandwidth model. In particular, the bandwith for the variable ATC in the direction Portugal to Spain decreases dramatically from 287.7 to 46.6 in the ATC PT-ES (Table 4); creating the additional complexity in the shape for the probability response plot (Fig. 10). A smoother shape is obtained with higher bandwidths in the "rule-of-thumb" non-parametric model. Nevertheless, the same tendency of increasing market splitting probability with lower ATC can be observed in all plots (Fig. 10). 
Logit - No correction for heteroskedasticity

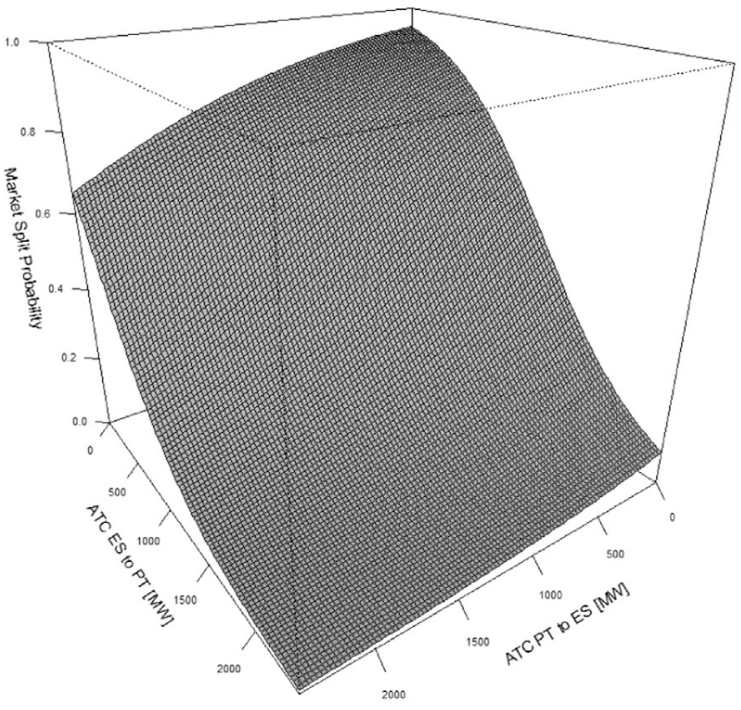

Non-parametric - Rule-of-thumb Bandwidth

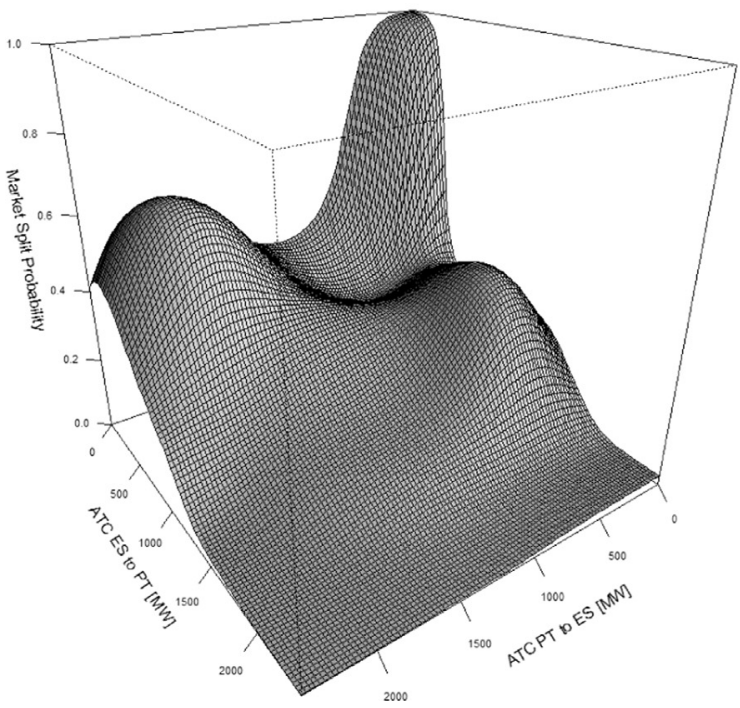

Logit - Corrected for heteroskedasticity

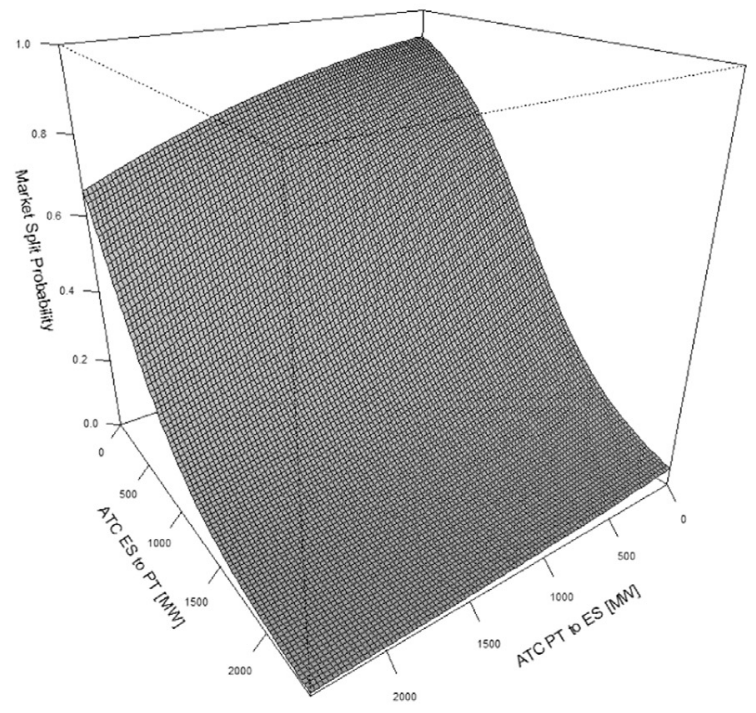

Non-parametric - Likelihood Cross-validation Bandwidth

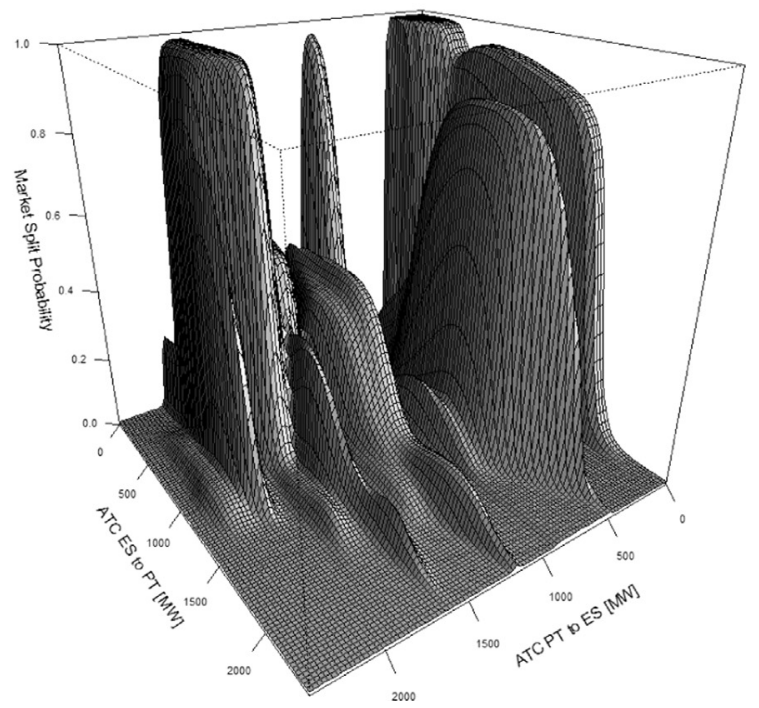

Fig. 10. Predicted probability response to ATC at mean power generation mix.

Considering the existing level of market splitting probability, we can conclude that the existing cross-border interconnection is adequate for the required electricity market integration, bearing in mind that it is actually higher (currently 25.6\%) than the EU recommendation of $10 \%$ of the peak demand of the smaller interconnected market (Amorim et al., 2014). Moreover, in order to maintain this reasonable market splitting probability level and spot electricity markets integration, the requirements for crossborder interconnection capacity should increase with increasing available wind power. This will allow further generation optimisation and security of supply, giving TSOs additional possibilities to balance the electrical grid. Otherwise, additional internal reserve capacities should be in place and available for the required grid balancing and system security, with the associated costs to the system. With increasing renewables without the adequate cross-border interconnection, thus increasing market splitting probability, these reserve capacities will normally be outside the dispatch merit order. A capacity payment mechanism might be necessary in order to have reserve power plants ready to be dispatched when required.

\subsection{Demand}

The different size of the electrical system between both Iberian countries also determines the market splitting behaviour. In general, lower demand in Spain creates importing electricity flows into Portugal thereby increasing market splitting probability. This is explained by the congestion of the interconnections due to the higher amounts of low marginal cost electricity available in Spain (including nuclear power due to its lack of flexibility). With high electricity demand in Spain, the increase in market splitting probability with increasing demand in Portugal is minimal. This is explained by the low marginal cost electricity being completely consumed internally and high marginal cost electricity dispatched, typically thermal power (Fig. 11).

Future demand in Iberia is dependent, not only on the economic performance, but also on policies that impact the electricity sector on the demand side. Policies for energy efficiency can control the growth of electricity demand, whilst the demand side response might create additional instruments for grid balancing and system security. Both avoid increasing cross-border transits of electricity, therefore decreasing market splitting probability. 
Logit - No correction for heteroskedasticity

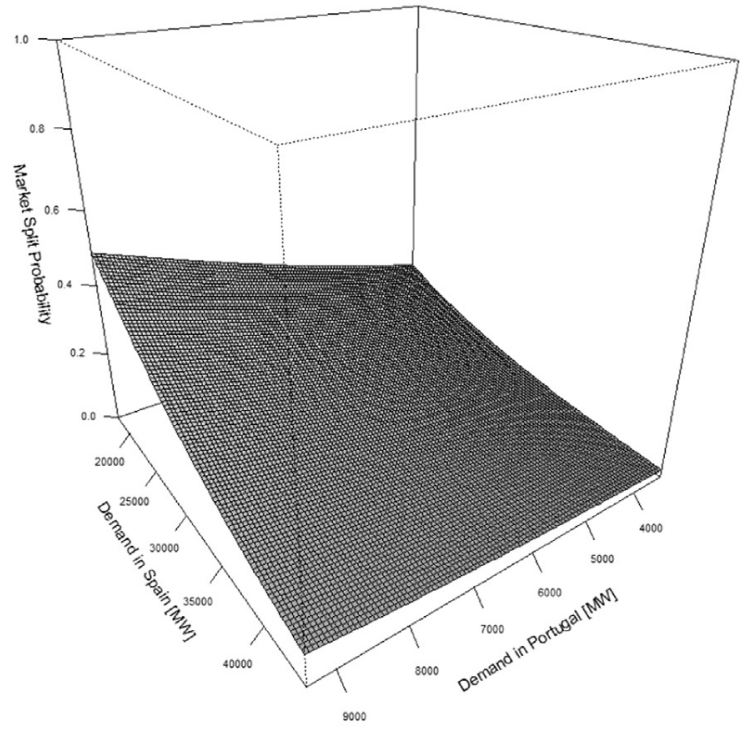

Non-parametric - Rule-of-thumb Bandwidth

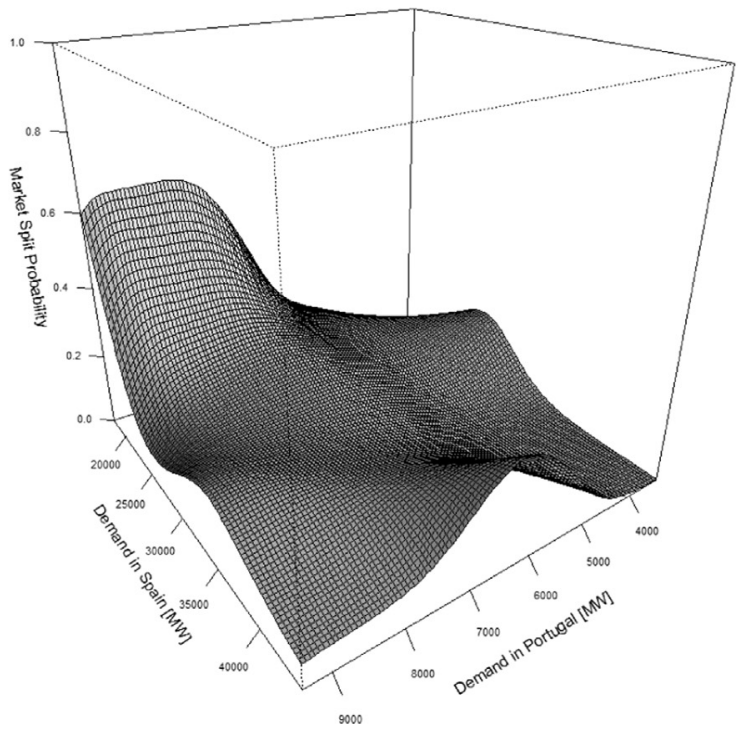

Logit - Corrected for heteroskedasticity

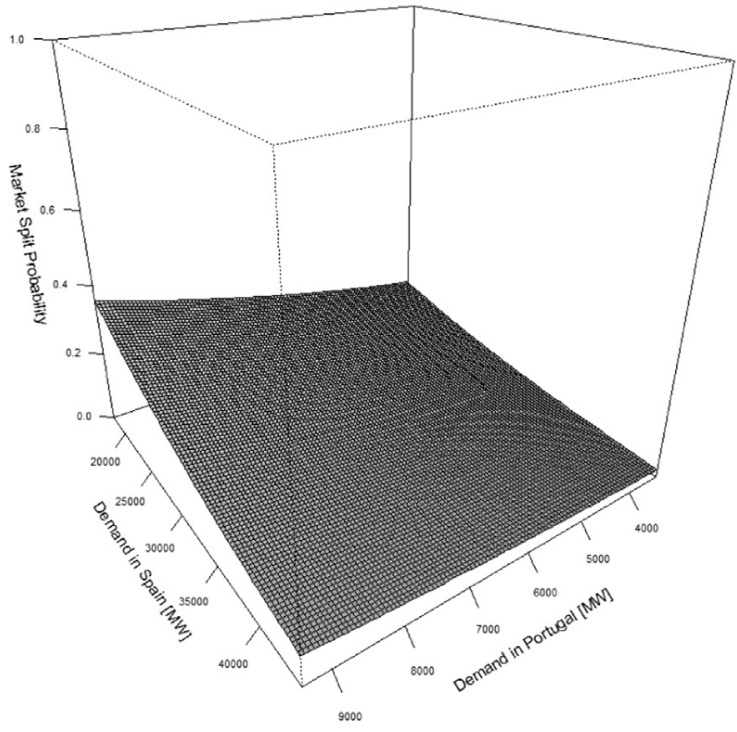

Non-parametric - Likelihood Cross-validation Bandwidth

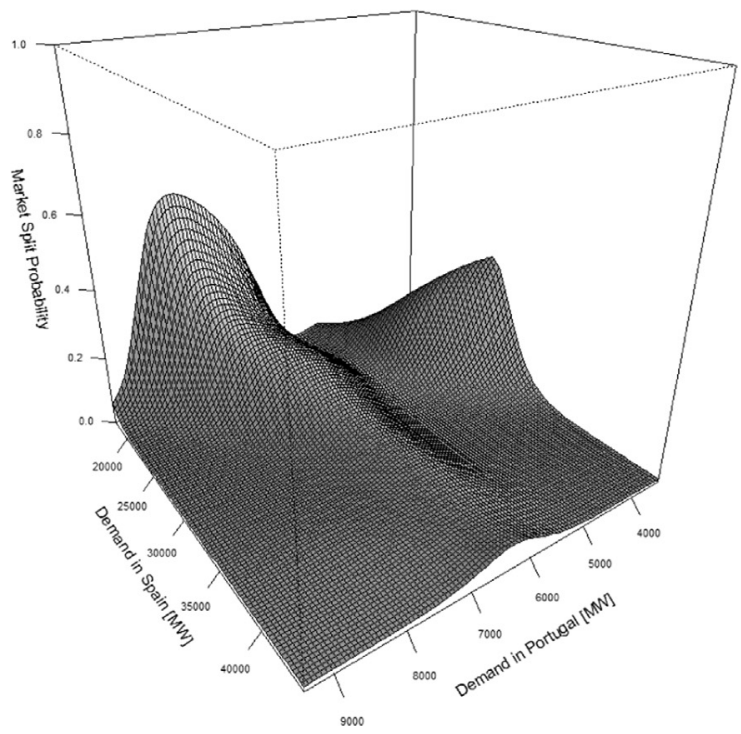

Fig. 11. Predicted probability response to demand at mean power generation mix.

\section{Conclusion and policy implications}

One of the benefits of spot electricity markets integration is the optimisation of RES-E generation. The determinants for electricity spot market splitting, including the influence of high penetration of wind power generation, together with the requirement to achieve an Iberian integrated electricity spot market, are herein studied.

Market splitting behaviour was modelled through logit and, for the first time to our knowledge, with non-parametric models, estimating the probabilities of its occurrence. Our models expose the fact that different sizes of electrical systems play a role in the behaviour of electricity market splitting. Fundamentally, it is also shown that when wind power generation is higher, or more generally with higher low marginal cost electricity such as nuclear power generation, market splitting probability increases, which is consistent with Salic and Rebours (2011) and Woo et al. (2011), thereby answering the first research question.

The results also confirm that the available cross-border interconnection capacity has an influence on market splitting, which answers to the second research question. To maintain the same market splitting probability level with increasing available low marginal cost electricity in the system, the requirements for interconnection capacity have to increase above the current EU recommended level of $10 \%$ of the peak demand of the smaller interconnected market. Actually Iberia has already surpassed this value reaching $25.6 \%$, aiming to achieve $3000 \mathrm{MW}$ in the near future, which will represent $32 \%$ of the maximum demand observed in the period considered in this study. As demonstrated, development of further wind power generating capacity should be followed by, and coordinated with, further interconnection capacity, in order to improve/maintain market integration. Moreover, an adequate cross-border interconnection capacity will avoid the internal development of dispatchable reserve capacity for balancing and grid security purposes. Policies governing the coordination of both interconnection development and renewable incentives should be designed. ACER through its coordination role should have a more pro-active stance considering RES-E 
expansion, namely adapting the Framework Guidelines on Electricity Grid Connection (ACER, 2014b).

Currently, as part of the climate and energy policy framework for the period 2020-2030, the cross-border interconnection target between Member States is set to be $15 \%$. However, regulation should also be adjusted and coordinated to allow different mechanisms for optimisation, deployment of effective energy storage facilities, wind power production curtailment and transmission system expansion. Furthermore, in order to attain RES-E optimisation and the desired further growth ("binding target" of $27 \%$ of RES-E in EU) without endangering market integration, the EU should consider within this framework, the increase of crossborder interconnection capacity recommendation above the currently discussed target of $15 \%$, depending on the existing and forecasted RES-E installed capacities in the area, in order to manage and optimise infrastructures.

\section{Acknowledgements}

This Work has been framed under the Energy for Sustainability Initiative of the University of Coimbra, supported by the R\&D Project EMSURE, Energy and Mobility for Sustainable Regions (CENTRO 070224 FEDER 002004) and also partially supported by the Portuguese Foundation for Science and Technology under project grant[s] PEst-OE/ EEI/UI308/2014.

This paper was written while the third author was a visiting scholar at the Economics Department of the University of Massachusetts, Amherst with support of the FCT grant \#SFRH/BSAB/ $1340 / 2013$.

We would also like to recognise the kind assistance provided by the Portuguese TSO REN for making data available, and by Prof. Jeffrey Racine and Prof. António Alberto Santos with software configuration for parallel processing of the non-parametric models.

\section{Appendix A. Supplementary material}

Supplementary data associated with this article can be found in the online version at http://dx.doi.org/10.1016/j.enpol.2015.06.013.

\section{References}

ACER, 2014a. ACER recommends the adoption of the Network Code on Forward Capacity Allocation [WWW Document]. URL 〈http://www.acer.europa.eu/Med ia/News/Pages/ACER-recommends-the-adoption-of-the-Network-Code-on-For ward-Capacity-Allocation.aspx $>$ (accessed 6.3.14).

ACER, 2014b. Framework Guidelines and Network Codes [WWW Document]. URL 〈http://www.acer.europa.eu/Electricity/FG_and_network_codes/Pages/default. aspx $>$ (accessed 11.5.14).

Aitchison, J., Aitken, C.G.G., 1976. Multivariate binary discrimination by the kerne method. Biometrika 63, 413-420

Amorim, F., Martins, M.V.M., Pereira da Silva, P., 2010. A new perspective to accoun for renewables impacts in Portugal, in: Proceedings of the 7th International Conference on the European Energy Market 2010. IEEE, pp. 1-6.

Amorim, F., Pina, A., Gerbelová, H., Pereira da Silva, P., Vasconcelos, J., Martins, V., 2014. Electricity decarbonisation pathways for 2050 in Portugal: a TIMES (The Integrated MARKAL-EFOM System) based approach in closed versus open systems modelling. Energy 69, 104-112.

Amorim, F., Vasconcelos, J., Abreu, I.C., Silva, P.P., Martins, V., 2013. How much roon for a competitive electricity generation market in Portugal? Renew. Sustain. Energy Rev. 18, 103-118.

Armstrong, M., Galli, A., 2005. Are day-ahead prices for electricity converging in continental Europe? An exploratory data aproach. Cern. Work. Pap. 33, 1-18.

Barth R. Apfelbeck J. Vogel P. Meibom P. Weber C. 2009. Load-flow based market coupling with large- scale wind power in Europe. In: Proceedings of the 8th International Work. Large-scale Integr Wind Power Power Syst. pp.1-8.

Batlle, C., 2011. A method for allocating renewable energy source subsidies among final energy consumers. Energy Policy 39, 2586-2595.

Batlle, C., Pérez-Arriaga, LJ., Zambrano-Barragán, P. 2012. Regulatory design for RES-E support mechanisms: Learning curves, market structure, and burdensharing. Energy Policy 41, 212-220.

Benatia, D., Johnstone, N., Haščič, I., 2013. Effectiveness of Policies and Strategies to Increase the Capacity Utilisation of Intermittent Renewable Power Plants. OECD Environment. Working Paper OECD Publ., pp. 1-49.

Biskas, P.N., Chatzigiannis, D.I., Bakirtzis, A.G., 2013. Market coupling feasibility between a power pool and a power exchange. Electr. Power Syst. Res. 104 116-128.

Boletín Oficial del Estado - Spain, 1997. Ley del Sector Electrico. Spain.

Bontemps C., Racine J.S., Simioni M. 2011. Nonparametric vs parametric binary choice models : an empirical investigation EAAE 2011 Congress Change and Uncertainty, Challenges for Agriculture, Food and Natural Resources 2011 pp. 113.

Bosco, B., Parisio, L., Pelagatti, M., Baldi, F., 2010. Long-run relations in European electricity prices. J. Appl. Econom. 25, 805-832.

Brown A., Müller S., Dobrotková Z. 2011. Renewable Energy - Markets and Prospects by Technology Report, International Energy Agency. pp.1-62.

Bunn, D.W., Gianfreda, A., 2010. Integration and shock transmissions across European electricity forward markets. Energy Econ. 32, 278-291.

Caramanis, M.C., Foster, J.M., Goldis, E. a., 2010. Load Participation in Electricity Markets: Day-Ahead and Hour-Ahead Market Coupling with Wholesale/ Transmission and Retail/Distribution Cost and Congestion Modeling. Smart Grid Commun. (SmartGridComm), 2010 First IEEE Int. Conf. 513-518.

Conselho de Reguladores do MIBEL, 2009. Descriç̃o do Funcionamento do MIBEL.

Coppens F., Vivet D. 2006. The single European electricity market: a long road to convergence Natl. Bank Belgium, Working Paper. pp. 1-53.

Crampes, C., Fabra, N., 2005. The Spanish Electricity Industry : Plus ça change Energy J. 26, 127-154.

Cruz, A., Muñoz, A., Zamora, J.L., Espínola, R., 2011. The effect of wind generation and weekday on Spanish electricity spot price forecasting. Electr. Power Syst. Res. 81, 1924-1935.

Cutler, N.J., Boerema, N.D., MacGill, I.F., Outhred, H.R., 2011. High penetration wind generation impacts on spot prices in the Australian national electricity market. Energy Policy 39, 5939-5949.

Davidson, R., Mackinnon, J.G., 2004. Econometric Theory and Methods, illustrate. Oxford University Press.

De Jonghe, C., Meeus, L., Belmans, R., 2008. Power exchange price volatility analysis after one year of trilateral market coupling. In: Proceedings of the 5th International Confernce of European Electricity Market EEM pp. 1-6.

De Vany, A.S., Walls, W.D., 1999. Cointegration analysis of spot electricity prices: insights on transmission efficiency in the western US. Energy Economics 21, 435-448.

Diário da República Portuguesa, 1995. Decreto-lei 187/95 de 27 de Julho. Portugal. EPEX, apx-endex, BelPEX, 2010. CWE MARKET COUPLING ALGORITHM pp. 1-19.

ERGEG, 2006. The Electricity Regional Initiative: Making Progress Towards a Single European Market. Electr. Reg. Initiat. - Fact Sheet, 1-5.

European Union, 2001. Directive 2001/77/EC of the European Parliament and of the Council of 27 September 2001 on the promotion of electricity produced from renewable energy sources in the internal electricity market. Off. J. Eur. Commun. L283, 33-40.

European Union, 2003. European Community Regulation 1228/2003/EC of the European Parliament and of the Council of 26 June 2003 on conditions for access to the network for cross-border exchanges in electricity. Off. J. Eur. Union L $176,1-10$.

European Union, 2009a. Directive 2009/28/EC of the European Parliament and of the Council of 23 April 2009 on the promotion of the use of energy from renewable sources and amending and subsequently repealing Directives 2001/ 77/EC and 2003/30/EC. Off. J. Eur. Union L140, 16-62.

European Union, 2009b. Regulation (EC) No 714/2009 of the European Parliament and of the Council of 13 July 2009 on conditions for access to the network for cross-border exchanges in electricity and repealing Regulation (EC) No 1228/ 2003. Off. J. Eur. Union L 211, 15-35.

Europex, 2009. Multi Regional Day-Ahead Price Coupling - Towards Implementation of the PCG Target Model. Conf. Proceedings, Florence Regul. Forum 1-5.

Europex, 2011. Status of Implementation of PCR for Day-Ahead Price Coupling. Conf. Proceedings, Florence Regul. Forum 1-7.

Eurostat, 2015. Eurostat - database [WWW Document]. URL 〈http://ec.europa.eu/ eurostat/data/database (accessed 3.6.15).

Figueiredo, N., Silva, P.P. da, 2012. Integration of South-West Spot Electricity Markets: An Update. In: Proceedings of the 12th IAEE - European Energy Conference. pp. 1-14.

Figueiredo, N., Silva, P.P. da, 2013a. Explanatory Variables on South-West Spot Electricity Markets Integration, in: Conference Proceedings, ICEE - Energy \& Environment: Bringing Together Economics and Engineering. pp. 1-13.

Figueiredo N., Silva P. 2013b. Integration of Central West Europe Spot Electricity Markets: An update. In: Proceedings of the 10th International Conference on the European Energy Market (EEM) IEEE. pp. 1-7.

Franco, A., Salza, P., 2011. Strategies for optimal penetration of intermittent renewables in complex energy systems based on techno-operational objectives. Renew. Energy 36, 743-753.

Furió, D., Lucia, J.J., 2009. Congestion management rules and trading strategies in the Spanish electricity market. Energy Econ 31, 48-60.

Galiana, F.D. Conejo, A.J., Gil, H.A., 2003. Transmission network cost allocation based on equivalent bilateral exchanges. IEEE Trans. Power Syst. 18, 1425-1431. 
Garrué-Irurzun, J., López-García, S., Red Eléctrica de España, S.A., 2009. Instrument of regulation and liberalization of the Spanish electricity market (1944-2004). Renew. Sustain. Energy Rev. 13, 2061-2069.

Gelabert, L., Labandeira, X., Linares, P., 2011. An ex-post analysis of the effect of renewables and cogeneration on Spanish electricity prices. Energy Econ. 33, S59-S65.

Genesi, C., Marannino, P., Montagna, M., Siviero, I., Zanellini, F., 2008a. A multilateral market coupling approach for the allocation of cross border transmission capacity. Proc. Univ. Power Eng. Conf.

Genesi, C., Rossi, S., Siviero, I., Marannino, P., Zanellini, F., Montagna, M., 2008b. Cross border transmission capacity allocation by multilateral market coupling. Proc. Mediterr. Electrotech. Conf. - MELECON 744-749.

Glachant. J.M. 2010. The Achievement of the EU Electricity Internal Market through Market Coupling EUI Working Paper, 1-25.

Hayfield, T., Racine, J.S., 2008. Nonparametric Econometrics : the np Package. J. Stat. Softw. 27, 1-32.

Henriot A., Lavoine, O., Regairaz, F., Hiroux-Marcy, C., Gilmore, J., Riesz, J., Yuen C. 2013. Market Design for Large Scale Integration of Intermittent Renewable Energy Sources Report, CIGRE WG C5-11. 1-131.

Higgs, H., 2009. Modelling price and volatility inter-relationships in the Australian wholesale spot electricity markets. Energy Econ 31, 748-756.

Hobbs, B.F., Rijkers, F.A.M., Boots, M.G., 2005. The more cooperation, the more competition? A Cournot analysis of the benefits of electric market coupling. Energy J. 26, 69-97.

Jacottet A. 2012. Cross-border electricity interconnections for a well-functioning EU Internal Electricity Market 1-17.

Jager, D., de, Klessmann, C., Stricker, E., Winkel, T., Visser, E., de, Koper, M., Ragwitz, M., Held, A., 2011. Financing renewable energy in the european energy market. Report, Ecofys, 1-264.

Jamasb, T., Pollitt, M., 2005. Electricity market reform in the european union : review of progress toward liberalization \& integration. Energy J. 26, 11-41.

Jónsson, T., Pinson, P., Madsen, H., 2010. On the market impact of wind energy forecasts. Energy Econ 32, 313-320.

Karova, R., 2011. Regional electricity markets in Europe: focus on the energy community. Util. Policy 19, 80-86.

Klessmann, C., Nabe, C., Burges, K., 2008. Pros and cons of exposing renewables to electricity market risks-A comparison of the market integration approaches in Germany, Spain, and the UK. Energy Policy 36, 3646-3661.

Kristiansen, T., 2007. A preliminary assessment of the market coupling arrangement on the Kontek cable. Energy Policy 35, 3247-3255.

Kurzidem, M.J., 2010. Analysis of Flow-based Market Coupling in. ETH Zurich.

Luna, L., Martínez, J., 2011. Impact of Wind Power Generation on the ATC value, in: 17th Power Systems Computation Conference. pp. 1-7.

Lynch, M.Á., Tol, R.S.J., O’Mall, M.J., 2012. Optimal interconnection and renewable targets for north-west Europe. Energy Policy 51, 605-617.

Mauritzen, J., 2010. What Happens when it's windy in Denmark? An empirical analysis of wind power on price volatility in the nordic electricity market. SSRN Electron. J., 1-29.

Meeus, L., Belmans, R., 2008. Electricity Market Integration in Europe. In: Proceedings of the 16th Power Systems Computation Conference, Glasgow, Scotland. pp. 1-5.

Meeus, L., Vandezande, L., Cole, S., Belmans, R., 2009. Market coupling and the importance of price coordination between power exchanges. Energy 34, $228-234$.

Meyer, N.I., 2003. European schemes for promoting renewables in liberalised markets. Energy Policy 31, 665-676.

Milligan M., Lew D., Corbus D., Piwko R., Miller N., Clark, K., Jordan, G., Freeman, L. 2009. Large-Scale Wind Integration Studies in the United States: Preliminary Results. Report, 8th Int. Work. Large Scale Integr Wind Power Transm. Networks Offshore Wind Farms 200915.

Ministerio de Industria y Energía - Spain, 1996. Protocolo para el Establecimiento de una Nueva Regulación del Sistema Eléctrico Nacional. Spain.

Mood, C., 2009. Logistic regression: why we cannot do what we think we can do, and what we can do about it. Eur. Sociol. Rev. 26, 67-82.

Moreno, B., López, A.J., García-Álvarez, M.T., 2012. The electricity prices in the European Union The role of renewable energies and regulatory electric market reforms. Energy 48, 307-313.

Moreno, F., Martínez-Val, J.M., 2011. Collateral effects of renewable energies deployment in Spain: Impact on thermal power plants performance and management. Energy Policy 39, 6561-6574.

Mulder, M., Scholtens, B., 2013. The impact of renewable energy on electricity prices in the Netherlands. Renew. Energy 57, 94-100.

NordPool, 2015. Explicit and implicit capacity auction [WWW Document]. URL 〈https://nordpoolspot.com/globalassets/download-center/pcr/how-does-itwork_explicit-and-implicit-capacity-auction.pdf $\rangle$ (accessed 3.17.15).

Oggioni, G., Smeers, Y., 2010. Market coupling and the organization of countertrading: separating energy and transmission again? Cent. Oper. Res. Econom.

Oggioni, G., Smeers, Y., 2013. Market failures of Market Coupling and countertrading in Europe: an illustrative model based discussion. Energy Econ. 35, $74-87$.
Okumura, H., Naito, K., 2004. Weighted kernel estimators in nonparametric binomial regression. J. Nonparametr. Stat. 16, 39-62.

OMIE, 2013. OMIE [WWW Document]. URL 〈http://www.omie.es/inicio $\rangle$ (accessed 3.13.15).

OMIE, 2014. Our electricity markets [WWW Document]. URL 〈http://www.omel.es/ en/home/markets-and-products/electricity-market/our-electricity-markets (accessed 7.28.14).

OMIE, 2015. OMIE Operating Rules [WWW Document]. URL 〈http://www.omie.es inicio/normativa-de-mercado/reglas-omie $>$ (accessed 3.17.15).

Pagan, A.R., Ullah, A., 1999. Nonparametric Econometrics. Cambridge University Press.

Park, H., Mjelde, J.W., Bessler, D. a, 2006. Price dynamics among U.S. electricity spot markets. Energy Econ. 28, 81-101.

Pellini, E., 2012a. Wholesale Spot Markets : Still a Way To Go. European Energy Conference, pp. 1-16.

Pellini, E., 2012b. Measuring the impact of market coupling on the Italian electricity market. Energy Policy 48, 322-333.

Racine, J.S. 2007. Nonparametric Econometrics: A Primer Found. Trends ${ }^{\mathbb{R}}$ Econom. vol. 3 pp. $1-88$.

Ragwitz, M. Steinhilber, S., Breitschopf, B., Isi, F., Resch, G., Panzer, C., Ortner, A., Busch, S., Vienna, T.U., Neuhoff, K., Boyd, R., Policy, C., Diw, I., 2012. RE-Shaping: Shaping an effective and efficient European renewable energy market. Rep. Compil. within Eur. Res., 1-111, Proj. RE-Shaping.

Red Eléctrica de España El sistema eléctrico español 2012 pp. 1-140.

Red Eléctrica de España, 2014. REE web site [WWW Document]. URL 〈www.ree.es (accessed 5.1.14).

Redes Energéticas Nacionais, 2012a. REN-2012-grupo-ren_historia.pdf [WWW Document]. URL 〈http://www.ren.pt/vPT/Investidor/GrupoREN/Historia/Pages/ investidor_grupo_ren-historia.aspx $\rangle$. (accessed 3.21.14).

Redes Energéticas Nacionais, 2012b. Estrutura Accionista [WWW Document]. URL 〈http://www.ren.pt/vPT/Investidor/InformacaoaoAccionista/Estrutur aAccionista/Pages/InvestidorGrupoRENEstrutura.aspx $>$ (accessed 3.21.14).

Redes Energéticas Nacionais, 2013. Caracterização das interligações em 31 de Dezembro de 2012 1-64.

Redes Energéticas Nacionais, 2014. REN web site [WWW Document]. URL $\langle$ www. ren.pt> (accessed 9.27.14)

Ruiz Romero, S., Colmenar Santos, A., Castro Gil, M.A., 2012. EU plans for renewable energy. An application to the Spanish case. Renew. Energy 43, 322-330.

Sáenz de Miera, G., del Río González, P., Vizcaíno, I., 2008. Analysing the impact of renewable electricity support schemes on power prices: The case of wind electricity in Spain. Energy Policy 36, 3345-3359.

Salic, G., Rebours, Y., 2011. Impact of German wind generation forecasts on net transfer capacities. Conf. Eur. Energy Mark. EEM 11, 635-640.

Sensfuß, F., Ragwitz, M., Genoese, M., 2008. The merit-order effect: a detailed analysis of the price effect of renewable electricity generation on spot market prices in Germany. Energy Policy 36, 3086-3094.

Silva, P.P. da, 2007. O sector da energia eléctrica na União Europeia: Evolução e Perspectivas. Coimbra University Press.

Silva, P.P. Da, Soares, I., 2008. EU spot prices and industry structure: assessing electricity market integration. Int. J. Energy Sect. Manag. 2, 340-350.

Smeers, Y., Oggioni, G., Allevi, E., Schaible, S., 2010. Generalized nash equilibrium and market coupling in the European power system. EPRG Work. Pap. 1016 $1-43$.

Söder, L., Hofmann, L., Orths, A., Holttinen, H., Wan, Y., Tuohy, A., 2007. Experience From Wind Integration in Some High Penetration Areas. IEEE Trans. Energy Convers. 22, 4-12.

The R Foundation for Statistical Computing, 2014. R.

Turvey, R., 2006. Interconnector economics. Energy Policy 34, 1457-1472.

Waniek D., Rehtanz C., Handschin E. 2009. Analysis of Market coupling based on a combined network and market model. In: Proceedings of the 2009 IEEE Bucharest Power Tech Innov. Ideas Towar. Electr. Grid Futur pp.1-6.

Weber, A., Graeber, D., Semmig, A., 2010. Market Coupling and the CWE Project. Zeitschrift für Energiewirtschaft 34, 303-309.

Woo, C.K., Zarnikau, J., Moore, J., Horowitz, I., 2011. Wind generation and zonalmarket price divergence: evidence from Texas. Energy Policy 39, 3928-3938.

Wooldridge, J., 2010. Econometric analysis of cross section and panel data, 2nd ed MIT Press.

Wooldridge, J.M., 2003. Introductory Econometrics - A modern approach, 2nd ed Thomson South-Western, Economic Analysis.

World Nuclear Association, 2015. Nuclear Power in Spain [WWW Document]. URL 〈http://www.world-nuclear.org/info/Country-Profiles/Countries-O-S/Spain/〉 (accessed 3.23.15)

Worthington, A., Kay-Spratley, A., Higgs, H., 2005. Transmission of prices and price volatility in Australian electricity spot markets: a multivariate GARCH analysis. Energy Econ. 27, 337-350.

Zachmann, G., 2008. Electricity wholesale market prices in Europe: Convergence? Energy Econ. 30, 1659-1671. 